\title{
Nuevas traducciones al castellano de las Confesiones de San Agustín
}

Las Confesiones son y han sido siempre la obra más conocida del Obispo de Hipona para los lectores de habla hispana igual que para los de otras lenguas. Como causa y efecto al mismo tiempo de esa realidad está el hecho de haber sido la más traducida, la que en más colecciones ha aparecido y la que más ediciones ha conocido.

Obviamente ha sido la más leída también, aunque quizá no tanto como pudiera deducirse de lo que acabamos de decir. En efecto, son muchos los que la adquieren con el sano deseo de leerla, guiados por los más diversos motivos (la celebridad del autor, de la obra, curiosidad estimulada por el título de la misma, obligaciones académicas, recomendaciones de terceras personas, ejercicio de lectura espiritual, etc.), pero tras un primer encuentro con el libro sienten una especie de frustración que podemos comparar de algún modo con la que experimentó el mismo Agustín en su primer acercamiento a la Escritura (Conf. III 5, 9), y la dejan de lado. Las razones son también diversas. A veces se debe a que no hallan en la obra lo que se imaginaban que iban a encontrar; a veces a que les resulta ininteligible, y en otras ocasiones a que la traducción en la que leen el escrito no se acomoda a los gustos del momento.

De aquí esa aparición constante de nuevas traducciones que intentan todas ellas retener al lector en compañía de la obra que, sin duda, es una de las cimas de la literatura universal, pero no sólo por su aspecto literario. Cada cual lo busca a su modo: unos mediante la acomodación del lenguaje, otros mediante el aumento de notas explicativas, otros eliminando lo que a su modo de ver dice poco a los hombres de nuestro tiempo.

El hecho de celebrarse el XVI centenario de la conversión de san Agustín debía de notarse necesariamente en este aspecto. Efectivamente, en los años inmediatamente anteriores y en el presente, el de la celebración, han aparecido varias traducciones nuevas, de las que vamos a ocuparnos particularmente en 
estas páginas. Pero como en el mercado librero español se pueden adquirir aún o se han podido adquirir hasta hace muy poco tiempo, o en cualquier caso, siguen en las manos de muchos usuarios traducciones antiguas, vamos también a hacer un ligero análisis de éstas en primer lugar. De aquí los dos apartados en que se dividen estas páginas.

\section{Traducciones antiguas}

Hasta hace muy poco tiempo, el lector de habla hispana, podía adquirir las Confesiones en las siguientes editoriales:

Apostolado de la Prensa. La traducción es del P. Francisco Mier, OSA, y, a partir de 1942, del P. Valentín Sánchez, S.J.

Biblioteca «El Buen Consejo» -El Escorial-. Traducción del P. Ángel Custodio Vega, OSA.

Espasa-Calpe (Colección Austral). Traducción del P. Eugenio Ceballos, OSA, con presentación de I. Quiles, S.J.

Ramón Sopena. Traducción de D. Lorenzo Riber.

Iberia (Colección «Grandes Maestros»). Traducción de Eugenio Ceballos, OSA, revisada y anotada por J.S.A.

Juventud (Colección «Libros de bolsillo Z»). Traducción de Agustín de Esclasans.

Bruguera («Libro clásico»). Traducción del P. Ángel Custodio Vega e introducción de José Luis Aranguren.

Sarpe (Colección «Los grandes pensadores»). Traducción del P. Eugenio Ceballos, OSA.

Biblioteca de Autores Cristianos. Traducción del P. Ángel Custodio Vega, OSA.

Aguilar. Traducción de D. Lorenzo Riber.

\section{A. La traducción del P. Eugenio Ceballos, OSA}

En sủ primera edición es muy antigua. Apareció ya en 1793 y es, por tanto, la más antigua de las que aquí consideramos ', aunque en las ediciones posteriores haya sido remozada.

1. Las otras tres traducciones castellanas: la del P. Ribadeneira, S.J., la del P. Sebastián Toscano, OSA, y la del P. Gante, OSA, no las consideramos aquí porque debido a su antigüedad y no haber sido reeditadas posteriormente no suelen hallarse a disposición de los lectores. 
Como texto latino utilizó el de la edición francesa de J. Martín.

De su traducción se puede decir que es clara y elegante, pero que nuestros gustos modernos ya se resienten un poco. Parte de su vocabulario ha perdido actualidad y lo mismo ha de decirse de muchos de sus giros, y hasta de la grafía de las palabras. Ediciones posteriores han introducido modificaciones, pero siempre son secundarias, y mantienen el mismo tenor.

La traducción es notablemente parafrástica y libre. Y dentro del recurso a la paráfrasis cabe destacar el uso sistemático a lo largo de toda la obra de lo que llamaremos «dobletes» o «tripletes», es decir, el servirse de dos o tres términos castellanos para traducir un único latino. Veamos un ejemplo de cada caso.

De «doblete». En un solo número (Conf. II 2, 3) encontramos todos estos casos:

$\begin{array}{ll}\text { novissimarum (rerum): } & \text { (cosas) bajas y transitorias } \\ \text { litus: } & \text { la orilla y playa } \\ \text { spinarum: } & \text { espinas y abrojos } \\ \text { formas: } & \text { la forma y regla } \\ \text { seclusarum: } & \text { que no habían de padecer ni sentir } \\ \text { non longe: } & \text { benigna y favorable } \\ \text { non longe: } & \text { no nos desampara ni se aleja }\end{array}$

De «triplete»:

II 5, 10: convenientiam: _ _.. correspondencia, conexión y enlace.

A veces introduce abundante texto de su cosecha, y en otras ocasiones intercala explicaciones que cuadraban mejor en nota. Por ejemplo: III 8, 15: grebas, que es la armadura que corresponde a las piernas.

Dejando de lado el aspecto de la paráfrasis, la traducción en general es fiel al pensamiento del Santo, aunque no sean raros los textos en que a nuestro parecer no lo ha entendido (por ej. en I 4, 4; I 5, 5). A veces, llevado por preocupaciones de carácter moralizante, destruye o elimina la imagen con que trabaja el autor, imagen que otras veces da la impresión de no captar, así como el significado de ciertos términos que Agustín utiliza de una manera fija y constante.

Mantiene la división tradicional en libros, capítulos y números. Cada libro va precedido de una brevísima síntesis de su contenido. Igualmente cada capítulo posee un epígrafe orientador para el lector. En la edición de SARPE y de ESPASA-CALPE contiene únicamente los diez primeros libros; en la edición de IBERIA, en cambio, aparece completa.

En la edición de ESPASA-CALPE, el texto va precedido de una presentación de I. Quiles, S.J., en la que pondera el valor de la obra, error incluido 
(atribuir a S. Ambrosio las palabras: «No puede perecer un hijo de tantas lágrimas»), haciendo hincapié en los aspectos filosóficos. Le precede igualmente el «Prólogo del Traductor» en el que resalta cómo la historia espiritual de Agustín es en última instancia la historia de todo hombre, y cómo las Confesiones pueden ayudar al hombre a conocerse. Es el aspecto moral el que más le interesa. Luego nos informa sobre su propia traducción. Las notas son relativamente abundantes y algunas bastante amplias. En su mayoría están tomadas de la edición francesa antes mencionada. Aunque abundan las de tono parenético, no faltan las que ilustran el texto, particularmente desde otros escritos del Santo. Juzgando desde hoy, las imprecisiones son numerosas. Carece de toda referencia bíblica, aunque las citas explícitas van en cursiva.

La edición de IBERIA tiene una breve presentación en que acentúa el valor y perennidad de la obra. La mejor presentación interna y el hecho de haber establecido frecuentemente otra puntuación, que abrevia la frase, hace su lectura más ágil. Acomoda igualmente la grafía y corrige algunas expresiones arcaicas. En esta edición desaparecen la gran mayoría de las notas, quedando algunas explicativas y reducidas a lo esencial; en cambio, aparecen en nota las citas bíblicas explícitas y todas las referencias literarias. De las tres presentadas, que recogen la traducción del P. Ceballos, ésta es, sin duda, la de más fácil lectura.

La edición de SARPE tiene una buena presentación exterior, pero al ser el tipo de letra tan diminuto su leçtura no resulta cómoda. Tiene una breve introducción dividida en cuatro secciones. La primera consiste en una presentación cronológica de los acontecimientos más importantes de la vida del Santo, en la que no faltan imprecisiones. La segunda se centra en la obra Las Confesiones, de la que resalta sobre todo su modernidad, pues «están conectadas con ciertas formas de sensibilidad contemporáneas». Concede particular importancia a los cuatro últimos libros de cuyo contenido hace una síntesis. La tercera sección coloca a san Agustín en su época, en el contexto de las relaciones del cristianismo con el mundo clásico, y en los tiempos posteriores a él, mostrando su influjo. Tampoco aquí faltan las imprecisiones e incluso errores. La cuarta sección es una bibliografía agustiniana en lengua castellana, referida a libros solamente. No es completa, ni tampoco lo pretende. Las notas aquí se reducen todavía más en número y en extensión, desapareciendo todas las de contenido moral-espiritual. Desaparecen de forma absoluta todas las referencias bíblicas.

\section{B) La traducción del P. Francisco Mier, OSA}

La traducción del P. Francisco Mier no se encuentra ya en el mercado librero, al ser sustituida en la edición de «El Apostolado de la Prensa» por la 
del P. Valentín Sánchez, S.J. Pero como aún se halla en las manos de no pocos lectores, haremos también una breve reseña de la misma, que apareció con motivo de celebrarse el XV centenario de la muerte del Santo.

Por su formato (nos referimos a la edición de 1941) es bastante manejable y el tipo de letra hace que su uso sea fácil y cómodo.

La introducción es suficientemente amplia. Después de un primer apartado en el que con un tono encomiástico -estimulado por el acontecimiento que se celebraba - canta las grandezas del Santo, considera los aspectos habituales en las introducciones de carácter científico a obras de este tipo: Las Confesiones en el conjunto de la obra de su autor, la fecha de composición y antecedentes; el porqué de la misma y su división; la doctrina filosóficoteológica y, por último, un repaso a las restantes traducciones. Introducción válida sin duda alguna para aquel entonces, pero que hoy ya queda corta por la evolución de los estudios agustinianos.

La obra aparece íntegra en sus trece libros. Sigue la división tradicional por lo que a los libros y capítulos se refiere. En cambio, por lo que se refiere a la otra división, en números, él establece una numeración continua para toda la obra, mientras que en la división tradicional, ésta se acaba en cada libro, para comenzar de nuevo en el siguiente. Esta novedad obedece, sin duda, a una intención precisa: favorecer la elaboración del índice de materias, evitando así el multiplicarse de las cifras, puesto que la única referencia será la de esa numeración continua.

Cada libro va precedido de un título general (alguno un tanto extraño, como el del libro X: El asceta de Tagaste), de la indicación de la edad a que se refiere cada uno, y de una introducción, relativamente larga, en la que expone no sólo el contenido material del mismo, sino también la relación lógica entre las ideas expuestas, así como las circunstancias en que escribió el autor. Es el momento que el traductor aprovecha para inocular al lector sus juicios y puntos de vista, preferentemente de carácter moral. No olvidemos que él presenta las Confesiones no como un libro de «cultura», sino de lectura espiritual. Esta misma introducción va incluida en la numeración continua de que antes hablamos. Cada capítulo lleva también un epígrafe corto.

Caso único entre las ediciones en lengua castellana de esta obra agustiniana hasta el presente, posee un índice suficientemente amplio de materias.

Las notas a pie de página son pocas, y desaparecen prácticamente a partir del libro XI. Se trata por lo general de notas eruditas y breves, con particular hincapié en las referencias literarias. En su mayor parte sigue las de la edición de P. De Labriolle, aparecida en «Les Belles Lettres». No faltan tampoco algunos errores.

Para su traducción el P. Mier disponía ya de mejores textos latinos: el 
del CSEL (1896), la edición de P. De Labriolle (Paris 1925) y la de Ramonio (Bibliotheca sanctorum Patrum, Roma 1909).

Él presenta la suya como «una revisión de la traducción del P. Ceballos, con objeto de acomodarla a los gustos de los lectores del s. XX, entre los que estos relatos de convertidos gozan de gran popularidad». Obviamente seguimos en el s. XX, pero ya casi 60 años después de que el P. Mier escribiese esas palabras. Los gustos de entonces son distintos de los de hoy y por eso la lectura de su traducción resulta ya dura para nosotros.

Si algo descuella en la traducción del P. Mier es el abuso de la paráfrasis, que supera con mucho a la del P. Ceballos. Con su traducción en las manos se obtiene frecuentemente la impresión de estar leyendo no la obra agustiniana, sino un comentario a la misma con carácter marcadamente moralizante. Un ejemplo de esa paráfrasis lo tenemos en la traducción de dos adjetivos que Agustín aplica a Dios: pulcherrime et fortissime. Su versión es esta: «No menos amable por vuestra perfecta y soberana belleza que temible por vuestra fuerza invencible» (Conf. I 4, 4). Todo ello da a la lectura un aire de pesantez y lentitud, que favorece poco a la obra.

\section{La traducción del P. Ángel Custodio Vega, OSA}

Más que de una traducción hay que hablar de dos traducciones. La primera apareció en 1932 en la «Biblioteca El Buen Consejo» de El Escorial. La segunda es la anterior totalmente refundida, hasta el punto de que en algunos libros se puede hablar de una nueva traducción, y fue preparada para la edición bilingüe de la Biblioteca de Autores Cristianos. En esta nueva forma siguió apareciendo en la «Biblioteca El Buen Consejo».

Lo que caracteriza a esta traducción, es, primero, que está hecha sobre un buen texto latino, la edición crítica del propio autor, que en su tiempo fue muy válida, aunque hoy haya sido superada ya por otras. $Y$, segundo, particularmente en la forma revisada, que es a la que nos referimos, el literalismo, quizá excesivo. Excesivo en cuanto que no se limita a ser fiel al pensamiento, sino también a la frase y hasta, a veces, al estilo latino de la obra. Por la ley del péndulo, la excesivamente parafrástica del P. Mier, dio la entrada a esta otra, apegada a «la letra». A pesar de que en la revisión ha dividido el texto en párrafos más cortos, aún no lo ha hecho lo suficiente, al menos para nuestros gustos. En consecuencia la lectura castellana sigue siendo dura, pesada y, a veces, de difícil intelección. La traducción del P. Vega es útil para quien, no pudiendo acercarse directamente al original latino, quiera situarse lo más cerca posible del texto del Santo, pero no para quien ajeno a escrúpulos de excesiva literalidad, busque una lectura cómoda y ágil. En efecto, la frase latina está debajo de la española, muy perceptible. 
Que sepamos, la traducción ha aparecido en tres editoriales: las dos ya mencionadas, Biblioteca El Buen Consejo y Biblioteca de Autores Cristianos, y Bruguera. Acerquémonos a cada una de ellas.

La de la Biblioteca El Buen Consejo es una edición popular. En un breve prólogo presenta la obra agustiniana. Es una edición completa con la división tradicional en libros, capítulos y números, con numeración nueva en cada libro. Éstos llevan una brevísima síntesis de su contenido e indican igualmente la edad del autor y los años a los que se refieren. Los capítulos llevan también un epígrafe orientativo para el lector. Carece de referencias bíblicas, aunque las citas explícitas van en cursiva. Las notas son relativamente abundantes y amplias para este tipo de ediciones.

La de la Biblioteca de Autores Cristianos está pensada primordialmente más para estudiosos y eruditos que para el pueblo sencillo. De ahí que sea bilingüe, la única española. El texto latino es el de la edición crítica del mismo $\mathrm{P}$. Vega, aunque ligeramente modificada con respecto a su primera aparición. De ahí también la amplia introducción, de más de 70 páginas, que es lo mejor y más completo de cuanto sę ha escrito en castellano sobre la obra. Contiene los siguientes apartados: el libro de las Confesiones. Precursores e imitadores de san Agustín. Motivo formal de las Confesiones. Valor histórico de las Confesiones. Los Diálogos de Casiciaco y las Confesiones. ¿A quiénes van dirigidas las Confesiones? Nombre, época y redacción de las Confesiones. Principales ediciones de las Confesiones (latinas y castellanas). Bibliografía de las Confesiones.

A este público estudioso van dirigidas también las numerosas notas de carácter erudito, unas y explicativas del texto, otras. La pena es que no se hallen a pie de página, sino al final de cada libro, lo que hace dificultosa su consulta. En esta edición, ni los libros ni los capítulos llevan epígrafe alguno. Concluye el libro con los textos en que el mismo Agustín habla de las Confesiones (Retractaciones II 6; El don de la perseverancia 20 y Carta 231, 6) y un cuadro cronológico de las obras del Santo.

Lamentablemente, en alguna edición (estamos pensando en la quinta que tenemos entre manos) son numerosos los errores tipográficos y faltan abundantes textos tanto del original latino como de la versión castellana.

Dejando de lado esos errores presentes en algunas ediciones, en conjunto es, sin duda la mejor edición de todas, aunque para el lector ordinario no es aconsejable porque su lectura le resultará pesada y, con frecuencia, difícil de seguir. La misma carencia de epígrafes indicada hace que el lector se encuentre sin esa mínima ayuda que le oriente en la lectura.

La de Bruguera es la misma de la BAC, en la edición más defectuosa, es decir, con errores incluidos, a excepción del texto latino y las referencias bíbli- 
cas. Las notas las recoge en su totalidad, ocupando una parte considerable del espacio. Lo único que aporta de nuevo es la introducción de José Luis Aranguren. Relativamente amplia para este tipo de ediciones (14 páginas) no carece de interés. Primero presenta a Agustín como el primer hombre moderno según la frase de A. von Harnack, y muestra aspectos en que se avera la afirmación. Luego se centra en el significado doble de la «confesión» y en el carácter de autobiografía y de memoria, a la vez, del escrito. Finalmente se detiene en las tres partes de la obra: libros I-IX (hombre interior y hombre exterior); X-XI (la memoria y el tiempo) y XII-XIII, resaltando particularmente lo moderno (o medieval) que se descubre en ella.

\section{D) La traducción de Lorenzo Riber}

La traducción de Lorenzo Riber, de la Real Academia Española, apareció en 1942. El éxito logrado por la misma ha sido notable, sobre todo en la hermosa edición presentada por la editorial Aguilar. Pero no ha sido sólo la presentación exterior la causa de ese éxito. Se fundamenta en méritos internos propios. Es una traducción que combina la fidelidad al pensamiento agustiniano con la exquisitez literaria, en la que no admite comparación con ninguna otra. Hablamos de fidelidad al pensamiento agustiniano, pero no es absoluta. Ante todo hay que decir que no es esclavo de la letra. Al contrario, a veces; dejándose llevar de la inspiración, se toma sus libertades, particularmente en eluso y en ocasiones abuso de los adjetivos. Sacrifica con frecuencia el detalle agustiniano a la elegancia de la frase. Una vez percibida la imagen del Santo, él la amplía con elementos de su propia invención.

La lectura se convierte en un placer para todo el que guste del arte literario. Es más, subyace el peligro de que el lector se olvide hasta cierto punto del contenido, absorto por la elegancia del estilo. Por otra parte, más de un lector deberá tener a mano un diccionario, si quiere seguir plenamente el texto, pues el léxico es selecto y muy fuera del usado en el lenguaje habitual.

La edición es completa en sus 13 libros. Solamente mantiene la división en libros y capítulos. Éstos con sus epígrafes muy poéticos y sugestivos, aquéllos con un título que recoge su contenido global y el dato cronológico. Las notas son escogidas y desaparecen en los tres últimos libros. Falta toda referencia bíblica.

El texto agustiniano va precedido de una larga introducción, en la que, en un estilo subido, lleno de resonancias literarias, particularmente clásicas, presenta la obra y, al hilo de la misma, la vida de Agustín, hasta donde le guían las Confesiones mismas.

La edición de la Editorial Ramón Sopena es idéntica en su contenido a la de Aguilar. Sólo varía la presentación. 


\section{E) Traducción del P. Valentín Sánchez, S.J.}

También ha gozado de amplia divulgación. La primera edición apareció en 1942 y luego se han sucedido otras hasta cuatro.

Aunque la primera edición apareció sin los tres primeros libros las siguientes los contenían todos. Mantiene la división clásica en libros, capítulos y números. Tanto capítulos como libros llevan un epígrafe. Las notas son breves y relativamente numerosas, con un marcado carácter moral-espiritual.

Como texto latino, ha escogido el de la edición crítica del P. A. Custodio Vega, con ligerísimas variantes.

Programáticamente se ha propuesto «ser fiel al pensamiento y juntamente al estilo agustiniano, reproduciendo en lo posible la concisión del original, en lo cual consiste... buena parte de su belleza». Y en verdad que respeta ese programa. Junto con la del P. Vega es la traducción más ceñida al texto agustiniano, participando de sus defectos y virtudes. Como virtudes destacamos precisamente esa cercanía al texto agustiniano, la fidelidad de la traducción, aunque no falten momentos en que, a nuuestro parecer, no ha acertado a expresar el pensamiento del Santo. Como defecto anotamos la falta de fluidez en el texto castellano, sus puntos con frecuencia demasiado largos. A nuestros oídos resulta ya muy extraño el uso del plural mayestático, para dirigirse a Dios, característica de todas las traducciones que hemos considerado, a excepción de la del P. Vega; el uso y abuso del pronombre enclítico (recibiéronme, dañaríale, parecióme, etc.), la introducción frecuente del sujeto entre el auxiliar y el participio (había yo claramente averiguado), etc. Por su parte, el vocabulario es sencillo, nada rebuscado, y por eso mismo muy comprensible.

\section{F) Traducción de Agustín de Esclasans}

La edición, de la editorial Juventud, es de 1968, aunque el prólogo lleva la fecha de 1945. Este prólogo, de mediana amplitud, se mantiene en un tono y lenguaje propio de sermón de iglesia. Presenta la figura de san Agustín, la obra de las Confesiones y, brevemente, algunos puntos centrales de la filosofía y teología del Santo. Es una mezcla de lugares comunes, generalidades, y de verdades a medias o, al menos, de ideas no bien expresadas. El autor se adentra en un terreno que no da muestras de conocer con la suficiente precisión.

La edición es completa en sus trece libros. La división es la tradicional, en libros, capítulos y números. Ni los libros ni los capítulos llevan epígrafe alguno. No contiene referencia bíblica alguna.

El texto latino seguido es el de la edición de P. De Labriolle en la colección «Les Belles Lettres» (Paris 1925). 
La traducción es bastante deficiente. Tal es, al menos, nuestro parecer. Si no es puro descuido, lo cual no deja de ser grave por la frecuencia, muchas veces no entiende el texto, traduce mal y altera el contenido, poniendo en boca del Santo algo que en verdad no dice. De vez en cuando se perciben también lagunas en el texto.

Desde el punto de vista literario tiene el valor de que se desliga de la frase latina. Pero su lectura es poco estimulante. Desaparece la viveza del original y el tono de frescura, en lo que influye entre otras cosas, lo que introduce de su propia cosecha. Extraña que en una edición de 1968 se mantenga todavía el plural mayestático para dirigirse a Dios. Modifica la grafía tradicional de algunos nombres geográficos. Así: Madauro, Tagasto.

Carece en absoluto de notas explicativas, por lo que el lector se encontrará con dificultad para entender no pocos textos.

N.B. Ocasionalmente se puede hallar también en alguna librería española otra traducción de las Confesiones por obra de Francisco Montes de Oca. Ha sido editada en Méjico por la editorial Porrúa, S.A., en la colección «Sepan cuantos...», n. ${ }^{\circ}$ 142. La primera edición vio la luz en 1970, y siete años después iba ya por la cuarta que es la que hemos podido consultar.

Dispone de una buena traducción que toca todos los problemas pertinentes. Elencamos los epígrafes: Ocasión y finalidad de las Confesiones; sentido de las Confesiones; las Confesiones como autobiografía; plan y unidad de las Confesiones; fecha de composición; el problema de la historicidad; el estilo de las Confesiones; bibliografía; cronología agustiniana. En dicha introducción, obra del traductor, usa la bibliografía moderna, aunque no siempre la cite. Las notas son abundantes en número y en extensión, con referencias frecuentes sobre todo a otras obras del Santo e igualmente a otros autores. Predomina la orientación filosófico-cultural sobre la teológico-espiritual. La traducción se caracteriza por su seguimiento pedísecuo del texto latino, por su fidelidad; su lectura, sin embargo, no resulta pesada, pues prevalece la claridad sobre otras consideraciones. Una edición muy útil. El texto va en doble columna.

\section{Nuevas traducciones}

En los últimos años han aparecido en España cuatro nuevas ediciones, en otras tantas editoriales, a saber, Editorial PALABRA (traducción de Pedro Antonio Urbina). $1 .^{a}$ edición en 1974; en 1984 va ya en su quinta edición.

Ediciones PAULINAS (traducción de Antonio Brambila Z.). En realidad 
esta edición es latino-americana; pero como se está vendiendo en las librerías españolas también la traemos aquí.

Ediciones AKAL (traducción de Olegario García de la Fuente). Recientemente aparecida.

BIBLIOTECA DE AUTORES CRISTIANOS - BAC minor - (traducción de José Cosgaya, OSA). La de más reciente aparición.

Ediciones CRISTIANDAD (traducción de Lope Cilleruelo, OSA). Esta traducción que debía haber salido ya a la luz pública, pues hace ya dos años que se entregó el texto a la editorial, espera aún el momento dichoso de su alumbramiento.

Detengámonos en cada una de ellas por separado.

\section{A) La traducción de Pedro Antonio Urbina (Ed. PALABRA)}

El formato 17 x 11 hace al libro muy manejable. La edición aparece en rústica.

Comienza con una EXCUSA del traductor con el fin de evitar malas interpretaciones e injustas acusaciones. En ella presenta lo que quiere hacer. Parte de una premisa: en la obra àgustiniana hay algo que no envejece y algo -mucho- que sí envejece. No envejece la idea, pero sí el arte de las Confesiones. Para un lector de hoy las Confesiones son literariamente viejas. Su estilo -dice - es terriblemente cargado, barroco, complicado, asfixiante, mientras que hoy la verdad llega sin oratoria, sin discursos ni grandilocuentes gritos; hoy la verdad se presenta casi desnuda... Y de ahí llega a una conclusión: la necesidad de hacer una «traducción libre en versión actualizada», para que el hombre de hoy reviva la aventura humana e interior de Agustín que es un hombre actual, actualísimo.

A continuación viene el texto de las «Confesiones» en una especie de 22 capítulos breves, sin numeración, que corresponden cada uno a una etapa geográfica y/o cronológica de la vida de Agustín. En cada uno de ellos incluye los textos narrativos de las Confesiones que corresponden a ese lugar y época, en diferentes unidades internas más o menos largas, olvidando por completo la división clásica de la obra, y alterando en algunos casos la sucesión de los textos. Cuando, al llegar al libro IX, la biografía de Agustín se agota por un período de su vida, el «traductor» se convierte en «autor», rellenando él personalmente las lagunas e informando de manera sumaria sobre los distintos lances de la vida del Santo, con acento particular sobre las obras que escribió. Cuando el orden cronológico le sitúa en el 399 y en Hipona, vuelve al texto de las Confesiones, sirviéndose de la parte «autobiográfica» del libro X. Como conclusión introduce otro «capítulo», en el que reconoce que los tres últimos libros no admiten esa «actualización» gramatical y que es preciso leerlos en el 
original. Luego incluye una lista no completa de las obras agustinianas, posteriores al año 400 , por orden cronológico, pero una cronología no actualizada conforme a los estudios recientes.

La traducción es programáticamente libre. Libertad que no se orienta a la alta, a la paráfrasis, sino a la baja, a la brevedad y concisión. Desaparece por completo el tono orante para convertirse el texto en pura narración. No hay diálogo con Dios, sino exposición a los hombres. Apenas hay preguntas, que son sustituidas por afirmaciones. Y si hay algunas, no se dirigen ya a Dios, sino a los hombres. No contiene ni una referencia bíblica, aunque las citas explícitas van en cursiva. Las notas que contiene son poquísimas, quizá menos de las necesarias, pero oportunas. En conjunto la lectura resulta ágil, agradable y en ningún modo pesada.

Las cinco ediciones que esta obra ha tenido en sólo diez años prueban muchas cosas: que san Agustín sigue siendo atrayente y en particular en su obra más conocida: Las Confesiones; que el público estaba ansioso de un texto que fuese legible, lejano tanto de la paráfrasis moralizante como de una excesiva esclavitud al texto latino; prueban también que el público ha aprobado el intento de P.A. Urbina.

Pero dicho esto, creemos deber añadir algo más. Estamos de acuerdo en que las Confesiones tienen algo de perecedero y algo de imperecedero; que la idea sigue vigente y que cada época tiene sus gustos artísticos que, salvo excepciones, el tiempo se encarga de devorar. Aunque con matizaciones, estamos conformes en general con lo escrito en la EXCUSA. Pero cuando entramos en el cuerpo del libro aparece nuestra extrañeza. Si el traductor quiere actualizar sólo aquello sobre lo que el tiempo ha triunfado, su arte literario, no su aportación intelectual y sinceridad vital, nos preguntamos qué entiende él por arte literario y qué por aportación intelectual. ¿Es que los cinco primeros capítulos de la obra, por ejemplo, son pura literatura, pura retórica, sin contenido de ideas? Leyendo el texto con frecuencia se obtiene la impresión de que el autor considera como literatura lo que es de contenido mayoritariamente doctrinal, porque es ahí donde más fácilmente introduce la tijera, y de que la aportación intelectual se halla preferentemente en las partes narrativas del escrito. Ante la obra tal como la presenta la editorial PALABRA uno se resiste a que se la titule Confesiones de san Agustín sin más, y hasta se diría que se da poco menos que un engaño. Si ha querido conservar lo que de «verdad» hay en la obra agustiniana, nos resistimos a creer que el «traductor» haya captado esa verdad. La impresión que se obtiene es que las Confesiones quedan reducidas a una biografía - tipo crónica- o poco menos. Admitiendo, por supuesto, la otra posibilidad: que nuestra lectura sea equivocada.

Sin duda, el libro ha llevado a muchos a acercarse a Agustín y a conocerlo 
más de cerca. Y seguimos manteniendo su validez, pero con otro título que no lo identifique sin más con las Confesiones.

\section{B) La traducción de Antonio Brambila Z.}

La edición de que disponemos, publicada en Bogotá en 1985, es de bolsillo, con un formato de $13 \times 9$, en papel semi-biblia, y cubierta de plástico, que la hace muy manejable.

El libro comienza con una «Nota del traductor» en la que, en base a una anécdota de G.K. Chesterton, expresa el sueño de todo buen traductor: «Así me hubiera gustado escribir mi libro si lo hubiera escrito en francés», y el sesgo que va a tomar su traducción. Partiendo de una premisa: el estilo de Agustín «es denso, conciso, incisivo» - recuérdese la opinión contraria de P.A. Urbina-, llega a la conclusión de que a san Agustín hay que prestarle palabras, pues el castellano no posee la densidad y la concisa fuerza expresiva del latín. Con todo, lo suyo no será una adaptación al castellano, sino una traducción propiamente dicha.

El texto latino de que se sirvió para la versión es el preparado por el P. Wangnereck, S.J., publicado por Marietti de Turín en 1938, ya como octava edición. No conocemos este texto, pero no deja de extrañar que no se haya servido de otro más reciente y más correcto ${ }^{2}$.

La edición presenta la obra en la totalidad de sus trece libros. Mantiene la división tradicional por lo que a libros y capítulos se refiere, aunque no siempre con exactitud, pues a veces divide arbitrariamente; la abandona sin embargo en lo que se refiere a los números, pues en lugar de poner la numeración continua dentro de cada libro, ha optado por dividir cada capítulo, según su criterio personal, aunque casi siempre las divisiones coincidan con las señaladas por los números de las otras ediciones. Sin duda es un inconveniente en esta edición por cuanto dificulta notablemente la consulta de citas.

Cada libro lleva una pequeña síntesis de su contenido e igualmente cada capítulo.

El mismo traductor indicaba - ya lo recordamos - que el castellano ha de prestar palabras a Agustín. Lo cual significa que no es una traducción estrictamente literal, o sometida servilmente a la letra latina. Pero no abusa de la paráfrasis. Con frases cortas generalmente, su lectura es fluida y resulta clara. Algunos capítulos son particularmente bellos por una parte y, por otra, a

2. Ediciones modernas de valor son las del P. A. Custodio Vega (Madrid 1932); la de F. Skutella en la Bibliotheca Teubneriana (Leipzig 1934) y la del P. Luc Verheijen, en el Corpus Christianorum (Turnholt 1981). Cada una de ellas ha mejorado la anterior. 
veces, ha logrado expresar el pensamiento agustiniano con una nitidez que es rara. Por este aspecto, supera, a nuestro parecer, a muchas de las anteriores.

Pero también hay que anotar sus puntos negativos.

\section{a) Errores de traducción o interpretación}

Son numerosísimos, aunque no todos de la misma entidad. Aquí traeremos solamente algunos de los muchos que hemos captado en una simple lectura, sin hacer una confrontación sistemática con el texto latino ${ }^{3}$.

1,2,2: Quo enim recedam extra coelum

Traduce: ¿Cómo podría yo salirme del cielo?

Debe ser: ¿Adónde...?

\section{I,4,4: Et quid diximus?}

Traduce: ¿Qué diremos, pues, de ti?

Debe ser: ¿Qué hemos dicho...?

I,11,18: Et terram potius unde postea formarer, quam ipsam iam effigiem committere volebat.

Traduce: Y no quiso exponer a ellas («tales batallas» = fluctus temptationum) la imagen suya que se nos da en el bautismo.

Debe ser: Y quería exponerles más bien el barro de que iba a ser formado, que no la misma imagen.

I,13,21: Euge, euge, dicitur ut pudeat, si non homo ita sit.

Traduce: También es cierto que decimos: Bien, muy bien, cuando el elogio es evidentemente inmerecido y queremos con él humillar a la gente.

Debe ser: Se grita a alguien: Bien, muy bien, para que él se avergüence de no ser así.

_._.: Et flebam Didonem ... sequens ipse extrema condita tua... et terra iens in terram

Traduce: Lloraba por la muerte violenta de Dido, tierra que vuelve a la tierra.

Debe ser: Lloraba por la muerte violenta de Dido, yo... tierra que vuelve a la tierra.

II,2,2: $\mathrm{O}$ tardum gaudium meum.

Traduce: Oh, mis pasos tardíos.

Debe ser: Oh, mi gozo tardío.

-_: Novissimarum rerum.

Traduce: de las cosas nuevas.

Debe ser: de las cosas últimas (inferiores).

3. Al dar nuestra traducción prescindimos totalmente de la formulación literaria, limitándonos a presentar el contenido. 
II,2,3: Abscissus propter regnum coelorum.

Traduce: Hubiera yo castigado mi carne por el reino de los cielos.

Debe ser: castrado por el reino de los cielos.

II,5,1,1: Quaere id quoque: cur ita.

Traduce: No deja de ser una explicación. Pero no lo es todo.

Debe ser: Pregunta también por qué es así.

II,6,12: Et nunc domine Deus meus, quaero quid me in furto delectaverit, et ecce species nulla est. Non dico sicut in aequitate atque prudentia, sed neque sicut in mente hominis atque memoria, et sensibus et vegetante vita.

Traduce: Ahora me pregunto Dios mío, por qué motivo pude deleitarme en aquel hurto. Las peras en sí no eran muy atractivas. No había en ellas el brillo de la equidad y de la prudencia, pero ni siquiera algo que pudiera ser pasto de la memoria, de los sentidos, de la vida vegetativa.

Debe ser: Y ahora pregunto yo, Señor Dios mío, qué era lo que me deleitaba en aquel hurto, porque él (el hurto, no las peras) no tiene atractivo alguno. No digo ya como el de la equidad y la prudencia; ni siquiera como el que se halla en la mente del hombre (falta), en la memoria, en los sentidos o en la vida vegetativa...

II,6,13: Quid te autem innocentius, quandoquidem opera sua malis inimica sunt?

Traduce: ni más inocente que tú, cuyas obras son siempre enemigas del mal.

Debe ser: ¿más inocente que tú, puesto que son sus obras las que son enemigas de los malos?

III,1,1: Amare amabam.

Traduce: quería ser amado.

Debe ser: Quería amar

-_: Fames mihi erat intus.

Traduce: Tenía hambre intensa.

Debe ser: ... hambre interior.

- - Sed quo inanior, fastidiosior.

Traduce: cuanto más miserable era...

Debe ser: cuanto más vacío...

III,2,3: Aestus inmanes tetrarum libidinum.

Traduce: Los terribles calores de las pasiones de la tierra.

Debe ser: Los terribles calores de las negras pasiones.

III,6,10: De quibus etiam vera dicentes philosophos trasgredi debui prae amore tuo. 
Traduce: Debí dejar de lado a los filósofos que no todo lo equivocaron y lo hice por amor tuyo.

Debe ser: Por amor tuyo debí remontar a los filósofos, aun diciendo verdad. (No dice que lo hiciera).

-_: Neque tu eras illa figmenta inania.

Traduce: Tú no estabas en aquellos vanos fragmentos.

Debe ser: Tú no eras tampoco aquellas vanas creaciones de la imaginación.

_-: Nec ea quae non videmus ibi, quia tu ista condidisti, nec in summis tuis conditionibus habes.

Traduce: Ni tampoco las que no vemos allí porque tú las creaste, pero en situaciones eximias de tu creación.

Debe ser: ... Ni tampoco las que no vemos allí (en el cielo), porque éstas (las que vemos en el cielo: sol y luna) tú las creaste, sin que las cuentes entre las obras superiores de tu creación.

III,8,15: Ut hoc se uterentur modo.

Traduce: para que de tal modo se comportasen.

Debe ser: Para que usasen los unos de los otros de tal modo.

III,8,16: Sed quae flagitia in te.

Traduce: ¿Qué malicia puede haber en ti...?

Debe ser: ¿Qué torpezas pueden darse en ti,...?

III,11,19: Eam consolatus es ut vivere mecum cederet et habere mecum eamdem mensam in domo?

Traduce: Aquel sueño consolador en que me vio vivir con ella, comer con ella a la misma mesa.

Debe ser: La consolaste hasta el punto que accedió a vivir conmigo y compartir la misma mesa en la misma casa.

IV,2,2: Et eos sine dolo docebam dolos, non quibus contra caput innocentis agerent, sed aliquando pro capite nocentis.

Traduce: Los dolos del arte, no para que los utilizasen en detrimento de los inocentes, sino para castigo de los culpables.

Debe ser: ... no para que los utilizasen en detrimento de los inocentes, sino para defender alguna vez a los culpables.

IV,2,3: Nonne fornicatur abs te, et fidit in falsis et pascit ventos.

Traduce: ... sino fornicar lejos de ti y apacentarse de los vientos.

Debe ser: ... sino fornicar lejos de ti, confiar en falsedades y apacentar vientos.

IV,3,4: Ut homo sine culpa sit, caro et sanguis et superba putredo.

Traduce: Con esto pretenden que el hombre no es culpable de ser carne y sangre y ensoberbecida putrefacción. 
Debe ser: A fin de que el hombre, que es carne y sangre y ensoberbecida putrefacción, no aparezca como culpable.

IV,4,7: Et ecce tu inminens dorso fugitivorum tuorum...

Traduce: Pero tú... era como si cabalgaras sobre los lomos de dos siervos tuyos que huían de tu lado.

Debe ser: Y he aquí que tú, alcanzando casi ya por la espalda a tus dos siervos fugitivos...

IV,4,9: Solus fletus... successerat amico meo in deliciis animi mei.

Traduce: Las lágrimas tomaron el lugar de mi amigo, delicia de mi alma.

Debe ser: Las lágrimas tomaron el lugar de mi amigo como delicia de mi alma.

IV,8,13: Alias spes.

Traduce: Otras imágenes.

Debe ser: Otras esperanzas.

$\mathrm{V}, 2,2$ : Et tu vides eos et distinguis umbras.

Traduce: Pero tú los ves y los distingues muy bien entre las sombras.

Debe ser: Pero tú los ves y adviertes que son sombras.

$\mathrm{V}, 5,8$ : Sed tamen quis quaerebat Manichaeum nescio quem etiam ista scribere.

Traduce: Alguno pidió a no sé qué maniqueo que escribiera.

Debe ser: Pero ¿quién pedía a no sé qué Manes que escribiera sobre estas cosas?

V,6,10: Per annos ferme ipsos novem.

Traduce: Durante esos nueve años bien corridos.

Debe ser: Durante esos mismos casi nueve años.

V,14,25: Quibus tamen philosophis, quod sine salutari nomine Christi essent, curationem languoris animae meae committere...

Traduce: Pero aún a tàles filósofos me negaba yo a confiarles la salud de mi alma, pues andaba aún lejos de la doctrina saludable de Cristo.

Debe ser: ... porque no se hallaba en ellos el nombre saludable de Cristo.

VI,3,3: Nec iam ingemescebam orando ut subvenires mihi.

Traduce: Yo no había aprendido aún a orar rogándote con gemidos que me ayudases.

Debe ser: Ya no te pedía con gemidos que me ayudases.

VI,4,5: Pulsans proponerem, quomodo credendum esset, non insultans opponerem.

Traduce: Había yo pulsado a la puerta de Ambrosio para preguntarle 
por sus motivos de creer lo que creía, sin ofenderlo con arrogante reproche por haber creído.

Debe ser: (Debí) proponer llamando (ante Dios) el modo cómo había que creer, no oponerme con insultos, como si creyesen (los católicos) lo que yo pensaba (que creían).

VI,7,11: Me minor natu.

Traduce: era un poco mayor que yo.

Debe ser: De menos edad que yo.

VI,9,15: Et tam parvus erat, ut nihil exinde domino suo metuens, facile posset totum indicare.

Traduce: estaba un chiquillo muy pequeño que ningún daño podía temer de su amo si lo decía todo.

Debe ser: Era el chiquillo tan pequeño que al no temer que de allí se derivase algún mal para su amo, fácilmente podía cantar todo.

VI,11,18: Figam pedes in eo gradu in quo puer a parentibus positus eram.

Traduce: Asentaré entonces mis pies en el paso en que de niño me pusieron mis padres.

Debe ser:.... en el peldaño, en el nivel, en que de niño...

VII,7,7: Aut hoc malum est quia timemus.

Traduce: o lo hacemos malo nosotros porque lo tememos.

Debe ser: ... o el mal está en el hecho de que tememos.

VII,9,14: Qui autem in cothurno tamquam doctrinae sublimioris.

Traduce: En cambio, aquellos que se levantan sobre el contorno de una más sublime doctrina.

Debe ser: ... sobre el coturno...

VIII,1,1: Sacrificium laudis.

Traduce: Sacrificio vespertino.

Debe ser: Sacrificio de alabanza.

VIII,2,3: Qui etiam ob insigne praeclari magisterii, quod cives huius mundi eximium putant, statuam romano foro meruerat.

Traduce: Que le habían concedido el alto honor, aceptado por él, de erigirle una estatua en el foro romano.

Debe ser: Quien, en atención a su preclaro magisterio, había merecido una estatua en el foro romano, cosa que los ciudadanos de este mundo consideran como el sumo (apetecible).

VIII,2,3: Quae iste senex Victorinus tot annos ore terricrepo defensitaverat. Traduce: Durante muchos años había el anciano rétor combatido con voz tonante a esos dioses extranjeros...

Debe ser: ... que había defendido con empeño...

VIII,2,5: Oblatum esse dicebat (Simplicianus) Victorino a discipulis. 
Traduce: Corrió el rumor de que los sacerdotes habían propuesto a Victorino.

Debe ser: Contaba (Simpliciano) que los discípulos habían propuesto a Victorino.

VIII,3,7: Et institutum est ut iam pactae sponsae non tradantur statim ne vile habeat maritus datam quam non suspiraverit dilatam.

Traduce: $Y$ ¿quién no ignora la costumbre corriente de que las esposas no se entreguen inmediatamente después del matrimonio? Pues no convendría que el hombre sintiera poco interés en recibir de inmediato como marido a la mujer por la cual no hubiera largamente suspirado como desposado que aguarda.

Debe ser: ... para que como marido no considere despreciable a aquella por la que no suspiró al diferírsele la entrega.

VIII,4,9: Absit enim ut in tabernaculo tuo prae pauperibus accipiantur personae divitum aut prae ignobilibus nobiles.

Traduce: ¡Ojalá nunca sean en tu casa recibidos los pobres con menor atención que los ricos, o los nobles mejor recibidos que los plebeyos!

Debe ser: ¡Lejos (de mí pensar) que en tu casa los ricos tengan preferencia sobre los pobres o los nobles sobre los plebeyos!

VIII,6,15: Et ambo iam tui aedificabant turre, sumpti idoneo relinquendi omnia et sequendi te.

Traduce: $\mathrm{Y}$ así tuyos ya los dos, dejaron todo por seguirte y comenzaron a edificar contando con expensas adecuadas.

Debe ser: ... levantaban la torre al precio justo de dejar todo y seguirte a ti.

VIII,8,20: Tam multa ego feci ubi non hoc erat velle quod posse; et non faciebam quod et incomparabili affectu amplius mihi placebat et mox ut vellem possem, quia mox ut vellem, utique vellem. Ibi enim facultas mea, quae voluntas, et ipsum velle iam facere erat; et tamen non fiebat, faciliusque obtemperabat corpus tenuissimae voluntati animae, ut ad nutum membra moverentur quam ipsa sibi anima ad voluntatem suam magnam in sola voluntate perficiendam.

Traduce: En cambio no me era posible algo que inmensamente quería: pues en un momento podía decir «quiero», pero en otro no me alcanzaban las fuerzas para tanto, y sólo quería querer. Porque el acto propio de la voluntad interior es el acto de querer, y querer es lo que ella hace. $Y$ en mí, sin embargo, no podía hacerse lo que yo tan grandemente quería. Fácilmente obedecía mi cuerpo a los más leves mandatos de mi alma moviéndose según su placer; pero mi alma no 
se podía obedecer a sí misma queriendo con voluntad eficaz lo que era su delicia.

Debe ser: Hice muchas cosas en las que no era lo mismo querer que poder, y en cambio, no hacía lo que me agradaba con un afecto incomparablemente mayor, y que lo hubiera podido con sólo quererlo, puesto que al instante de quererlo lo quería en efecto. Pues allí, el poderlo era lo mismo que quererlo y el quererlo, era ya realizarlo. $Y$ con todo no lo hacía, y más fácilmente obedecía mi cuerpo al más leve deseo de mi alma, de modo que los miembros se movían a su capricho, que la misma alma a sí misma, para realizar su gran deseo en su sola voluntad.

IX,1,1: Et hoc erat totum, nolle quod volebam et velle quod volebas. Traduce: Y esta miseria no estaba en otra cosa que en no querer lo que tú querías y en querer en cambio lo que tú querías.

Debe ser: Y todo consistía en no querer lo que yo quería y en querer lo que tú querías.

- - Omni voluptati dulcior, sed non carni et sanguini.

Traduce: Tú eres más dulce que todos los placeres a la carne y a la sangre.

Debe ser: Tú eres más dulce que todo placer, pero no para la carne y la sangre.

- - : Et omni honore sublimior, sed non sublimibus in se.

Traduce: Y más sublime que todo honor, pero no de ese honor con que muchos se sienten en sí mismos encumbrados.

Debe ser: Y más sublime que todo honor, pero no para los que colocan en sí su excelencia.

IX,2,2: Insanias mendaces.

Traduce: en las mendicidades.

Debe ser: en las locuras engañosas.

IX,4,4: Tanquam in pausatione anhelantibus, testantur libri disputati cum praesentibus.

Traduce: como les pasa a los gladiadores en los momentos de descanso, lo atestiguan los libros polémicos que surgieron entonces de mis conversaciones con los amigos presentes.

Debe ser: ... los libros dialogados...

-_: Ad alia maiora properanti?

Traduce: $i . . .$, cuando tanta prisa tengo por contar todavía otras menores?

Debe ser:... mayores.

$\mathrm{X}, 3,4$ : Quo fructu, quaeso, etiam hominibus coram te confiteor per has litteras adhuc quis ego sim, non quis fuerim? 
Traduce: Dime, pues, ¿qué utilidad van a sacar de mis confesiones los que lean este libro cuando vean que digo no sólo lo que fui, sino también lo que soy ahora que escribo?

Debe ser: ¿Con qué fruto, pregunto, confieso también ante ti a los hombres por medio de este escrito lo que soy yo ahora, no lo que he sido?

$\mathrm{X}, 4,6$ : Hic est fructus confessionum mearum, non qualis fuerim, sed qualis sim.

Traduce: Éste será el fruto de mis confesiones: mostrar no ya lo que fui, sino lo que ya soy.

Debe ser: Éste es el fruto de confesar no lo que fui sino lo que soy.

$\mathrm{X}, 6,10$ : Cur non omnibus eadem loquitur?

Traduce: ¿Por qué entonces no todos hablan de la misma manera?

Debe ser: ¿Por qué no habla lo mismo a todos?

$\mathrm{X}, 26,37$ : Omnes unde volunt consulunt, sed non semper quod volunt audiunt.

Traduce: Te consultan sobre lo que quieren oír, pero no siempre quieren oír lo que tú les respondes.

Debe ser: Todos te consultan sobre lo que quieren, pero no siempre escuchan lo que quieren.

-_-: Sed potius hoc velle quod a te audierint.

Traduce: sino que está sinceramente dispuesto a oír lo que tú le digas. Debe ser: sino más bien a querer lo que de ti oiga.

$\mathrm{X}, 37,60$ : Laude vero ut careamus atque in eo experiamur quid possumus, numquid male vivendum est et tam perdite...

Traduce: Mas para que nadie nos alabe y sepamos a qué atenernos sobre nuestra situación no es en modo alguno indispensable que vivamos mal.

Debe ser: ¿Acaso hemos de vivir mal y tan perdidamente... para vernos privados de la alabanza y conocer a dónde llegan nuestras fuerzas?

XI,2,2: Tibi confiteri scientiam et imperitiam meam, primordia illuminationis meae et reliquias tenebrarum mearum.

Traduce: Confesarte mi ciencia y mi experiencia que han sido preámbulos de tu iluminación y reliquias de antiguas tinieblas mías.

Debe ser: Confesarte mi ciencia y mi ignorancia, los inicios de tu iluminación y lo que queda de mis antiguas tinieblas.

XI,8,10: Quia et loquitur nobis.

Traduce: Que habla de nosotros, y también, con nosotros.

Debe ser: Que habla a nosotros, que nos habla. 
XIII,2,2: Nisi per idem verbum revocarentur ad unitatem tuam.

Traduce: Si esta palabra no la hubieras revocado a tu unidad.

Debe ser: Si no las hubieras vuelto a llamar a tu unidad mediante la misma Palabra.

XIII,2,3: Aversi a te, nostro lumine.

Traduce: mientras nuestra luz vivió apartada de ti.

Debe ser: al apartarnos nosotros de ti, luz nuestra.

XIII,7,8: Neque enim loca sunt quibus mergimur et emergimus. Quid similius et quid dissimilius?

Traduce: Porque no hay lugar en que nos hundamos y luego salgamos a flote, cosas ambas del todo diferentes.

Debe ser: Nuestro hundirnos y nuestro emerger no es de carácter local; pero ¿hay cosa más parecida y menos parecida a la vez?

XIII,14,15: Semper confitebor illi.

Traduce: $Y$ siempre me confesaré a ti.

Debe ser: $Y$ siempre le confesaré.

XIII,15,17: ... coelos, opera digitorum tuorum, disserena oculis nostris nubilum quo subtexisti eos.

Traduce: ... cielos, obra de tu mano serena, la nube que ha velado nuestros ojos.

Debe ser: ... los cielos, obra de tu mano; purifica nuestros ojos de la nube, con que tú los has cubierto.

-—: Quia subterpositis solidasti ea.

Traduce: que tú consolidas mediante la sumisión de tus siervos.

Debe ser: puesto que los afirmaste para los que le están sometidos.

XIII,15,18: Qui non opus habent suscipere firmamentum hoc et legendo cognoscere verbum tuum.

Traduce: que no necesitan recibir su firmeza de las Escrituras para conocer mediante su lectura a tu Verbo.

Debe ser: que no tienen necesidad de mirar este firmamento (la Escritura) y por su lectura conocer tu palabra.

XIII,19,24: Fiant et tibi luminaria in firmamento coeli.

Traduce: Y así habrá luminarias en tu cielo.

Debe ser: Conviértanse para ti en luminarias en el firmamento del cielo.

b) Se salta numerosos textos. Por ejemplo, no aparece traducido lo indicado en cursiva:

1,4,4: Portans et implens et protegens

I,5,5: Ecce aures cordis mei ante te, Domine 
1,7,11: Unius diei vita super terram

1,13,21: Amicitia mundi huius fornicatio est abs te

II,3,7: Contemnebaris a me, filio eius, filio ancillae tuae

II,3,7: Quae iam de medio Babilonis fugerat

II,8,16: FALTA TODO EL CAPÍTULO

III,6,10: Et Paracleti consolatoris nostri

IV,3,6: $A b$ illo et per illum

IV,15,26: Dicebam parvulis fidelibus tuis, civibus meis

VII,9,13: Testimonium perhibeat de lumine, non est tamen ipsa lumen

VII,9,13: Quia vero in sua propria venit et sui eum non receperunt; quotquot autem receperunt eum dedit eis filiis dei fieri credentibus in nomine eius, non ibi legi

VII,21,27: Faltan once líneas del CC al final del capítulo

$\mathrm{X}, 7,10$ : Faltan cuatro líneas del $\mathrm{CC}$ al final del capítulo

$\mathrm{X}, 35,54$ : Non solum: vide quid luceat, quod soli oculi sentire possunt... vide quid oleat

$\mathrm{X}, 40,65:$ Et attendi vitam corporis mei de me sensusque ipsos meos

XIII,16,19: Et scit

En cambio, en XIII,15,16 aparecen repetidas dos líneas.

c) Errores tipográficos. Veamos algunos ejemplos:

I,13,21: una muerte por la (falta) que moría yo lejos de ti

I,17,27: los desperdiciaba (el ingenio)

- : enfrentado $=$ afrentado

V,5,9: con pertinencia $=$ con pertinacia

- - : cómo no juzgar semejante audacia con detestable demencia y de no condenarla con firme reprobación.

$\mathrm{V}, 11,21:$ Helvidio $=$ Elpidio

VI,4,6: Mi escepticismo no llegaba $a$ (falta) la insania de

VI, 10,16: conciliario $=$ consiliario

VII,9,15: en imágines en $(=\mathrm{de})$ hombres corruptibles

VIII,2,3: padre... del obispo Anselmo (=Ambrosio)

VIII,3,6: Porque de la salvación de alguno... nos alegra(mos) mucho más...

IX,2,2: $s u$ color (=so color)

IX,8,17: Mis hacinamientos (= hacimientos = acciones) de gracias

$\mathrm{X}, 31,43$ : que ojalá $y$ (sobra) le bastara

$\mathrm{X}, 31,44$ : y se (falta) alegra de no saber.

$\mathrm{X}, 33,49$ : no me moverían así si (falta) de otra manera los cantasen.

Con frecuencia: puntuaciones equivocadas. 
d) Notas no acertadas

Nota a 1,16,25: la alusión no es al diluvio, sino al madero de la cruz Nota a VII,10,16: poner una iluminación de orden místico en esta etapa de la vida de Agustín es por lo menos sorprendente.

En conjunto, las notas, no muy numerosas y breves, están bien colocadas y ayudan notablemente a la comprensión del texto.

\section{e) Términos y giros que nos resultan extraños}

No hay que perder de vista que la traducción ha sido realizada en Hispanoamérica. Ello significa que aparecen con frecuencia términos que son poco o nada usados en España. Por ejemplo: laudanza, $(\mathrm{I}, 1,1)$, mociones de los ojos (I,8,13), fincar (IV,11,16; VIII,1,1), dubitación (VIII,1,1); llamado (por llamada, invitación: X,8,13; XIII,10,11), etc. Asimismo un hipérbaton que molesta a nuestros oídos: «lo habré siempre de buscar» $(I, 18,28)$; «eran en ese libro censurados» (III,4,8); un uso quizá excesivo de la voz pasiva: «cuando fue llegado el tiempo» (IX,6,14); «fue vuelto a encontrar» $(\mathrm{X}, 31,45)$; una influencia sajona en el uso de los adjetivos antes del sustantivo: «de pasados tiempos» $(\mathrm{XI}, 13,15)$; «en secreto lugar» $(\mathrm{IX}, 7,16)$; el pronombre enclítico: recibiéronme $(\mathrm{I}, 6,7)$; gozábame $(\mathrm{I}, 10,16)$; ruégote $(\mathrm{XI}, 8,10)$; no falta tampoco el loísmo: «lo $(=\mathrm{le})$ hacen sufrir» $(\mathrm{II}, 3,5)$; etc.

N.B. La misma traducción de A. Brambila aparece publicada en Argentina, como ya antes, en 1980, en México, también en Ediciones Paulinas y en edición de bolsillo. La introducción es de Gustavo Vietti. En ella, de forma breve y esquemática, presenta las razones de la actualidad perenne de la obra agustiniana. Recogemos los títulos: su estilo literario; su trasparencia humana; su encarnación; su conocimiento de sí mismo; su experiencia de Dios; su apasionamiento en todo. En el texto de Brambila introduce algunas correcciones de léxico o formas expresivas con el fin de adaptar dicha traducción al lector rioplatense y en otras ocasiones para hacer más comprensible el pensamiento agustiniano. No hemos podido examinar esas variantes. Además, cada libro se inicia con una breve síntesis de su contenido, más que un mero epígrafe.

\section{C) La traducción de Olegario García de la Fuente}

Olegario García de la Fuente es catedrático de filología latina de la Universidad de Málaga. Este dato, junto con la editorial que publica la obra, AKAL/Clásica condiciona la introducción. Ésta, que va precedida de un cua-, dro cronológico de la vida de san Agustín, consta de dos partes. La primera es 
una brevísima biografía del Santo, pequeños errores incluidos (a los 28 años comienzan sus primeras dudas sobre la doctrina maniquea; que Simpliciano le habla de la vida de los monjes). La segunda se centra ya en la obra misma. Comienza examinando los problemas literarios que presenta (fecha de composición, plan y unidad, motivo y finalidad) para pasar luego al problema de la historicidad, recogiendo de una manera sintética los datos de la investigación moderna; finalmente se detiene en la lengua y estilo de la obra, mostrando cómo en ella se combinan el latín clásico, el latín bíblico y el latín cristiano, deteniéndose en presentar ejemplos de estos dos últimos aspectos. Como conclusión pasa revista a las distintas ediciones, indicando que tomará como base de su traducción la del CC de M. Verheijen; luego a las distintas traducciones en castellano, informándonos sobre los principios que van a regir la suya: intentará ser fiel al pensamiento de Agustín, totalmente fiel, pero sin caer en una literalidad excesiva.

En verdad su traducción, precisamente por su condición de filólogo, queda muy lejos de las libertades, ciertamente no excesivas, que se tomaba el traductor de la última edición presentada. Por otra parte tampoco es tan literal como la del P. Valentín Sánchez o la del P. Custodio Vega, pero les sigue de cerca. Se separa sobre todo en la frase. Fiel en general a las palabras, rompe con la estructura de la frase latina, defecto de las dos últimas mencionadas, para acomodarse al lenguaje de nuestros tiempos y para hacer menos fatigosa y hasta agradable, a veces; la lectura de esta obra siempre difícil. El período latino, en ocasiones excesivamente largo, hasta requerir respirar hondo, para leerlo todo de un tirón, es desmembrado en frases cortas, que además hacen más inteligible el texto. No obstante, no faltan momentos en que se olvida de ello y nos ofrece párrafos un tanto largos (por ejemplo en $1,9,15 ; 1,18,29$; VI,3,4; IX,10,25).

La edición en rústica y con un formato de $17 \times 10,5$, es completa, es decir, contiene los 13 libros. La división es la tradicional en libros, capítulos y números, salvo al final del libro XIII en que, evidentemente por error, la cambia: en lugar de XIII,28,43, él mantiene el XIII,27,43, y a partir de ahí en adelante la numeración de los capítulos va retrasada en un número (donde debía ser, por ej. XIII,29,44 en su edición es XIII,28,44) y en consecuencia el libro XIII numera un capítulo menos. Ni los libros ni los capítulos llevan epígrafe alguno; únicamente la referencia numérica.

El texto elimina toda referencia bíblica, y va todo en letra redonda, incluidas las citas bíblicas explícitas, salvo en los casos en que se comenta explícitamente de un texto (libro IX: salmo $4 .^{\circ}$; libros XI-XIII: Gen 1,1ss.).

Las notas son más bien abundantes y breves; dado el carácter de la edición uno habría esperado más notas eruditas. Pero sin duda sirven las que tiene. 
El libro perfecto no existe, y menos cuando se trata de traducir una obra de arte, cima del pensamiento y de la literatura, como son las Confesiones. Pero aun admitida la imposibilidad de la perfección absoluta y la dificultad de traducir las Confesiones, teniendo en cuenta que las traducciones son muchas en las distintas lenguas, esperábamos de esta edición mucho más.

Los defectos que le encontramos son los siguientes:

\section{a) Numerosos errores de traducción}

También aquí nuestra lectura ha sido únicamente de esta edición castellana, sin confrontarla sistemáticamente con el original latino. Sólo después de acabada la lectura hemos recurrido al texto del CC para confirmar si había error donde nosotros lo habíamos sospechado. El resultado es el siguiente, sin detenernos en otros numerosos datos de menor relieve ${ }^{4}$.

1,2,2: Quo te invoco, cum in te sim?

Traduce: ¿En dónde te invoco estando yo en ti?

Debe ser: Adónde te invoco...

I,13,21: Dolerem, quia non legerem quod dolerem.

Traduce: me habría dolido con tal de no leer lo que me dolía.

Debe ser: Hubiera sentido dolor si no hubiera podido leer lo que me causaba dolor.

I,14,23: Temptationes martyrum.

Traduce: tentaciones de los mártires.

Debe ser: las pruebas (los tormentos) de los mártires.

II,2,3: A paradiso tuo seclusarum.

Traduce: que habian de estar excluidas de tu paraíso.

Debe ser: que estaban excluidas de tu paraíso.

II,6,13: Quid te autem innocentius, quandoquidem opera sua malis inimica sunt?

Traduce: $\mathrm{Y}$ ¿qué hay más inocente que tú, cuando hasta los malos reciben el castigo de sus obras?

Debe ser: $i \ldots$ puesto que son sus obras las que son enemigas de los malos?

II,7,15: Non me derideat ab eo medicum aegrum sanari a quo sibi praestitum est ut non aegrotaret.

Traduce: no se ría de mí por haber sido curado, estando él enfermo, por el mismo médico que le concedió no caer enfermo.

Debe ser: No se ría de mí por haber sido curado estando (yo) enfermo, por el médico...

4. También aquí hemos de repetir lo dicho en nota 3. 
II,8,16: Et discernit umbras eius.

Traduce: disipa mis sombras.

Debe ser: discierne sus (del corazón) sombras.

II,8,16: Facinus.

Traduce: pecado (en general).

Debe ser: «crimen» (un pecado específico que consiste en causar daño a otro).

III,1,1: Secretiore indigentia.

Traduce: con una infelicidad muy oculta.

Debe ser: con una carencia más secreta (aún).

- - Rui etiam in amorem quo cupiebam capi.

Traduce: caí además en los lazos del amor, cosa que no quería que me sucediera.

Debe ser: ... amor, en que deseaba quedar atrapado.

III,2,3: Cum autem sese amitebant.

Traduce: cuando no lo conseguían (el fin de sus depravados amores).

Debe ser: cuando se perdían el uno para el otro.

III,6,10: Ceterum cor inane veri.

Traduce: en lo demás, su corazón no poseía la verdad.

Debe ser: por lo demás, su corazón...

-_: De quibus etiam vera dicentes philosophos transgredi debui prae amore tuo.

Traduce: $\mathrm{Y}$ aunque dijeran sobre estos elementos algunas cosas verdaderas, yo tuve que remontarme por encima de los filósofos...

Debe ser: ... filósofos, debí remontarme... (No dice que lo hiciera, sino lo contrario: debía haberlo hecho, pero no lo hizo).

- -: Quibus certiores sunt phantasiae corporum eorum, quae sunt, et eis certiora corpora, quae tamen non es.

Traduce: En comparación con ellos son más reales las fantasías de los cuerpos que existen y cuerpos más reales que ellos, pero tú no eres ellos.

Debe sèr: En comparación con ellos son más reales las imágenes creadas por la imaginación a partir de los cuerpos que existen, y los cuerpos más reales que ellas, pero tú no eres estas cosas.

III,7,12: Nesciebam enim aliud quod vere est.

Traduce: Yo no conocía otra cosa que lo que realmente es.

Debe ser: Yo no conocía otra cosa, lo que realmente es.

- - : Et quid in nobis esset, secundum quod.essemus et recte in Scriptura diceremur ad imaginem Dei, prorsus ignorabam.

Traduce: Ignoraba también completamente qué es lo que hay en no- 
sotros para que existamos, y que la Escritura nos dice con verdad que estamos hechos a imagen de Dios.

Debe ser: Ignoraba completamente qué es lo que hay en nosotros por lo que somos y con razón se dice en la Escritura que somos hijos de Dios.

III,8,16: Aut in aliquo prosperatus ei quem sibi aequalis timet aut aequalem dolet.

Traduce: o el que ha conseguido la prosperidad en relación con el que teme que le iguale o se duele de que ya le ha igualado.

Debe ser: o el que ha conseguido la prosperidad respecto a aquel del que teme que le iguale o se duele de que le haya igualado ya.

-_: In eum usum qui est contra naturam.

Traduce: para emplearlas en algo que es contra natura.

Debe ser: ... en aquel uso que es contra natura (ya específico).

III,9,17: Multa itaque facta que hominibus improbanda viderentur.

Traduce: muchas cosas que parecerían reprochadas a los hombres.

Debe ser: muchas cosas que parecerían dignas de reproche a los hombres.

III,12,21: Istarum lacrimarum.

Traduce: de tantas lágrimas.

Debe ser: de esas lágrimas.

IV,2,2: Quid est enim ventos pascere quam ipsos pascere?

Traduce: Pero ¿qué es apacentarse de viento más que apacentarlos a ellos, es decir...?

Debe ser: Pero ¿qué es apacentar vientos, sino apacentarlos a ellos...?

IV,7,12: O stultum hominem inmoderate humana patientem!

Traduce: Qué necedad humana que tiene que sufrir desmesuradamente cosas humanas.

Debe ser: ¡Necio el hombre que sufre desmesuradamente por las cosas humanas!

-_: Impatientem portari a me.

Traduce: incapaz de llevarla por mí mismo.

Debe ser: que no toleraba que la llevase yo.

IV,8,13: Dissentire interdum sine odio.

Traduce: discutir a veces sin enfadarnos.

Debe ser: disentir a veces sin enfadarnos... (más adelante, el mismo error).

IV,10,15: Tantum dedisti eis, quia partes sunt rerum, quae non sunt omnes simul. 
Traduce: Sólo les concediste el ser, pues son partes de las cosas que no existen todas a la vez.

Debe ser: Sólo eso les diste...

IV,16,31: Nec erubesco... confiteri tibi in me misericordias tuas.

Traduce: Y no me avergüenzo... de hacerte esta confesión por tu misericordia para conmigo.

Debe ser: Y no me avergüenzo de proclamar tus misericordias para conmigo. (Es útil, en bien del lector, distinguir los dos significados de confiteor).

$\mathrm{V}, 2,2$ : Et distinguis umbras.

Traduce: Y los descubres hasta en las sombras.

Debe ser: $\mathrm{Y}$ adviertes que son sombras.

V,9,16: Et melior eram puer.

Traduce: siendo yo entonces mejor que soy ahora.

Debe ser: era mejor siendo aún niño. (En la traducción de $O$. G. se entiende que era mejor cuando se hallaba en Roma, que en el momento en que escribe).

V,12,23: Saluberrime docebat salutem.

Traduce: enseñaba con absoluta ortodoxia la salvación.

Debe ser: enseñaba de la forma más sana la salvación. (Saluberrime no indica nada referido a la ortodoxia).

VI,1,1: Respondit mihi credere se in Christo quod priusquam...

Traduce: diciéndome que ella creía en Cristo y, por tanto, que antes de...

Debe ser: diciéndome que ella tenía la certeza, fundamentada en Cristo, de que antes de...

VI,5,8: Multo tamen plures quam si nec tanto apice auctoritatis emineret, nec turbas gremio sanctae humilitatis hauriret.

Traduce: Y serían muchos más, si la autoridad no fuera tan excelsa o no eliminara a las turbas del seno de su santa humildad.

Debe ser: Muchos más, sin embargo, que si no fuese tan excelso el prestigio de su autoridad y no absorbiese a las turbas en el seno de su santa humildad.

VI,6,9: Et mentienti faveretur ab scientibus.

Traduce: y a pesar de decirles mentiras recibiría el aplauso de los entendidos.

Debe ser: ... el aplauso de los que sabían (que mentía).

VI,11,19: Ac non potius huius negligentiae supplicia luenda?

Traduce: ¿No tendré otra felicidad que soportar el suplicio de esta negligencia? 
Debe ser: ¿Es que no tendremos que expiar el castigo de esta negligencia?

VI,13,23: Quo me iam coniugatum baptismus salutaris oblueret, quo me in dies gaudebat aptari.

Traduce: para que así, una vez casado, recibiera el bautismo salvador. Mi madre me encontraba cada día más apto para el matrimonio. Debe ser: para que una vez casado me lavara el bautismo salvador, para el que (el bautismo) ella (su madre) con gozo me veía cada día más preparado.

VII,3,4: Ne ipse fierem quod quaerebam.

Traduce: Ni yo llegara a ser lo que buscaba.

Debe ser: No fuera que me convirtiese en lo que buscaba.

VII,5,7: Fides Christi tui... in multis quidem adhuc informis.

Traduce: Mi espiritu mal formado todavía en muchas cosas...

Debe ser: La fe en tu Cristo todavía...

VII,6,9: Inter suos esse primarios.

Traduce: eran los principales entre sus parientes.

Pensamos:... entre sus conciudadanos.

VIII,2,3: Qui etiam ob insigne praeclari magisterii, quod cives huius mundi, eximium putant, statuam foro romano meruerat.

Traduce: que en premio de su preclaro magisterio, cosa que los ciudadanos de este mundo tienen en la máxima estima, había merecido... una estatua en el foro... (Lo que los hombres estiman no es -creemos- ese magisterio, sino la estatua en el foro. El texto de la traducción indica lo contrario).

VIII,6,13: Sicut ego vendebam dicendi facultatem, si qua docendo praestari potest.

Traduce: Como yo vendía la elocuencia, si es que puede venderse la elocuencia con la enseñanza.

Debe ser: Si es que algo (de la elocuencia) se puede trasmitir con la enseñanza.

VIII,6,15: Et ambo iam tui aedificabant turrem sumptu idoneo relinquendi omnia et sequendi te.

Traduce: Y comenzaron a edificar la torre de que habla el evangelio con la condición indispensable de abandonar todas las cosas y seguirte.

Debe ser: ... al precio justo de...

VIII,11,25: Et cum verbum ibam iam in placitum.

Traduce: Con mis palabras iban ya mis deseos.

Debe ser: $Y$ con las palabras caminaba ya a la realización (a dar la orden). 
IX,2,2: Et redemptus a te iam non redirem venalis.

Traduce: $Y$ no volver ya más a vender mi enseñanza.

Debe ser: $Y$ rescatado por ti, no venderme ya nunca más.

IX,4,11: $O$ in id ipsum.

Traduce: $\mathrm{O}$ dormir en el mismo instante.

Debe ser: Oh, en el mismo (ser).

IX,8,17: Hac ratione praecipiendi et auctoritate imperandi.

Traduce: Con este modo de mandar y con la costumbre que tenía para imponerse.

Debe ser: Con este modo de ordenar y con la autoridad para mandar...

IX,13,37: Civium meorum in aeterna Jerusalem.

Traduce: Fueron mis conciudadanos en la Jerusalén eterna. (Sobra el «fueron»; es simple aposición).

$\mathrm{X}, 2,2$ : Quo fructu tibi confitear.

Traduce: el provecho que saco de confesarme a ti.

Debe ser: ... de confesarte a ti. (Es habitual en el traducción esta forma de hacerlo: confiteri tibi lo vierte en confesarme a ti sin tener en cuenta los dos significados de «confiteri»).

$\mathrm{X}, 4,5$ : Bona mea instituta tua sunt et dona tua; mala mea delicta mea sunt et iudicia tua.

Traduce: Mis obras buenas son obras tuyas y dones tuyos. Mis malas obras son mis pecados y tus juicios.

Pensamos: Mis bienes son... mis males...

$\mathrm{X}, 4,6$ : Hic est fructus confessionum mearum, non qualis fuerim, sed qualis sim.

Traduce: La utilidad de mis confesiones está no en lo que he sido, sino en lo que soy, y en lo que confiese.

Debe ser: Éste es el fruto de confesar no lo que he sido, sino lo que soy.

$\mathrm{X}, 6,9$ : Et responsio eorum, species eorum.

Traduce: Y su respuesta era la apariencia de sus cualidades.

Debe ser: Y su respuesta, su belleza. (Aunque quizá quiera decir lo mismo, no está claro).

$\mathrm{X}, 6,10$ : Nec respondent ista interrogantibus nisi iudicantibus.

Traduce: Y la razón es que las cosas no responden a los que las investigan, sino a los que saben juzgarlas.

Debe ser: Pero las cosas no responden a los que sólo interrogan, sino a los que aplican también el juicio.

$\mathrm{X}, 30,41$ : Et de ipso coniugio melius aliquid quam concessisti monuisti. 
Traduce: $\mathrm{Y}$ con respecto al matrimonio me aconsejaste algo mejor de lo que en él has concedido. (Sobra el «en él» que cambia el sentido).

$\mathrm{X}, 31,46$ : Non inmunditiam obsonii, sed inmunditiam cupiditatis.

Traduce: No la suciedad de los platos, sino la suciedad de la concupiscencia.

Sería mejor (para evitar falsas interpretaciones): no la impureza de los alimentos, sino la de la concupiscencia.

$\mathrm{X}, 35,56$ : Et te facientem quod vis das mihi et dabis libenter sequi.

Traduce: Pues tú haciendo lo que quieres, me concedes y me concederás lo que acepto de buen grado.

Debe ser: Y tú que haces lo que quieres te das a mí y me concederás el seguirte con agrado.

$\mathrm{X}, 42,67$ : Sed quia stipendium peccati est mors, hoc habet conmune cum hominibus, unde simul damnetur in mortem.

Traduce: Pero como el precio del pecado es la muerte, lo que tiene de común con los hombres es que será condenado con ellos a la muerte. Debe ser: Mas como el estipendio del pecado es la muerte, es éste, el pecado, lo que tiene en común con los hombres, origen de la común condena a muerte.

XI,2,2: Primordia illuminationis meae.

Traduce: la luz que me diste al principio.

Debe ser: el comienzo de mi iluminación (lo primero que has iluminado).

$\mathrm{XI}, 7,9$ : Et ideo verbo tibi coaeterno simul et sempiterne dicis omnia quae dicis et fit quidquid dicis ut fiat; nec aliter quam dicendo facis.

Traduce: Por eso, con tu palabra, eterna como tú, haces a la vez y eternamente todas las cosas que haces, y se hace lo que mandas que se haga.

Debe ser: ... eterna como tú, dices todo lo que dices, y se hace cuanto dices que se haga, ni lo haces de otra manera que diciéndolo.

$\mathrm{XI}, 8,10$ : Quia et per creaturam mutabilem cum admonemur.

Traduce: Porque hasta las creaturas mudables cuando nos reprenden.

Debe ser: ... cuando nos avisan (amonestan).

: Cum autem redimus ab errore cognoscendo utique redimus.

Traduce: cuando nos convertimos de nuestro error, nos convertimos sabiéndolo.

Debe ser: ... nos convertimos mediante el conocimiento

$\mathrm{XI}, 9,11$ : In quantum dissimilis ei sum.

Traduce: porque me veo incompatible con ella.

Debe ser: en cuanto le soy desemejante. 
XI,10,12: Nonne ecce pleni sunt vetustatis suae.

Traduce: ¿No están movidos por una vieja objeción...?

Debe ser: ¿No están llenos de su propia vetustez...?

$\mathrm{XI}, 30,40$ : Et stabor et solidabor in te, in forma mea, veritate tua.

Traduce: Yo estaré en ti en la forma que tengo firme como una roca. Estaré firme en tu verdad.

Debe ser: Me mantendré firme y sólido en ti, en mi forma, tu verdad.

XII, (passim): Invisibilis et incomposita.

Traduce: caos y desorden, cuando en realidad son dos conceptos distintos (invisibilis indica el momento anterior a la iluminación).

XIII,1,1: Ex desiderio quod spiras ei.

Traduce: con el deseo de que la inspires.

Debe ser: con el deseo que le inspiras.

-_: Et praevenisti omnia bona merita mea.

Traduce: $\mathrm{Y}$ has apreciado todas mis buenas acciones.

Debe ser: $\mathrm{Y}$ te has anticipado a todos mis buenos merecimientos.

-_: Neque ut sic te colam quasi terram, ut sis incultus si non te colam; sed ut serviam tibi et colam te, ut de te mihi bene sit.

Traduce: Te ruego que no cultive tu amistad como se cultiva la tierra, de modo que si no cultivara tu amistad, te vieras privado de mi cuidado. Que te sirva y cultive tu amistad para que me encuentre bien contigo...

Debe ser: Ni te cultive como a la tierra, de modo que quedes inculto si no te doy culto; antes bien, para que te sirva y te dé culto, para que mi bien me venga de ti.

XIII,2,3: Similis abysso, tui dissimilis.

Traduce: semejante al abismo, diferente de ti.

Debe ser: semejante al abismo, desemejante a ti.

-_-: Nam et nos qui secundum animam creatura spiritalis sumus, aversi a te, nostro lumine, in ea vita fuimus aliquando...

Traduce: hasta nosotros que por el alma somos criaturas espirituales separadas de ti, nuestra luz, fuimos alguna vez tinieblas en esta vida...

Debe ser: hasta nosotros que por el alma somos criaturas espirituales, separadas de ti, nuestra luz, fuimos alguna vez tinieblas.... (la diferente puntuación cambia el sentido).

XIII,3,4: Neque enim eius informitas placeret tibi, si non lux fieret, non existendo, sed intuendo illuminantem lucem eique cohaerendo, ut et quod utcumque vivit et quod beate vivit, non deberet nisi gratiae tuae, conversa ... ad id... 
Traduce: Porque ni siquiera su carencia de forma te agradaría si no se convirtiese en luz, no siendo ellos la luz que ilumina, sino sólo intuyéndola, y uniéndose a ella. De tal modo que no sólo deban a tu gracia el simple hecho de vivir y el hecho de vivir una vida feliz. Convertida ... en lo que no puede cambiarse...

Debe ser: Pero ni siquiera su carencia de forma te agradaría si no se hiciese luz, no por el simple hecho de existir, sin o contemplando la luz que ilumina y adhiriéndose a ella, de forma que el simple vivir y el vivir felizmente no lo debiera sino a tu gracia, convertida hacia lo que no puede cambiar ni a mejor ni a peor.

XIII,15,16: Coelum plicabitur ut liber.

Traduce: El cielo se pliega como un libro.

Debe ser: ... se plegará...

XIII,17,21: Habens in se semen secundum similitudinem.

Traduce: teniendo dentro su semilla por ser semejante a nosotros.

Debe ser: ... su semilla según la semejanza.

XIII,20,26: Producant aquae reptilia animarum vivarum.

Traduce: Que produzcan las aguas un hervidero de animales vivientes.

Debe ser: ... las aguas reptiles de almas vivas. (3 veces traduce reptilia por hervidero; no sabemos la relación; además, destruye la imagen de Agustín).

- - Repserunt enim sacramenta tua, Deus, per opera sanctorum tuorum. Traduce: Tus misterios, Señor, fueron un hervidero por las obras de tus santos. (Cf. lo dicho antes).

b) No parece comprender el pensamiento del Santo

II,2,2: Sed non tenebatur modus ab animo usque ad animum, quatenus est luminosus limes amicitiae.

Traduce: no guardaba la moderación que debe haber en el amor mutuo, de persona a persona, ya que el límite de la amistad es algo luminoso.

Debe ser: pero no guardaba yo la justa medida: de alma a alma, hasta donde es luminosa la frontera de la amistad (Agustín contrapone la amistad que se fundamenta en el alma, a la que se fundamenta en el amor del cuerpo. Sólo en el primer caso es luminosa, serena; en el segundo es tenebrosa).

I1,3,6: Et inclinatae in ima voluntatis suae.

Traduce: ... de su voluntad inclinada a las cosas de aquí abajo. (No es tanto -creemos- «las cosas de aquí abajo» cuanto las cosas ínfimas, de inferior categoría en la jerarquía del ser). 
II,5,10: Ceterisque sensibus est sua cuique accomodata modificatio corporum.

Traduce: en los demás sentidos hay una cierta modalidad propia de las cosas.

Debe ser: para los demás sentidos los cuerpos tienen una cierta modalidad que se les ajusta.

- - Cum his omnibus infimis pulchris.

Traduce: con todas las cosas hermosas que hay aqui abajo. (Véase antes a II,3,5).

III,3,5: Fugitivam libertatem.

Traduce: una libertad fugitiva.

Debe ser: la libertad (de que goza) un fugitivo (es decir, mínima).

$\mathrm{V}, 3,4$ : Sicut volatilia.

Traduce: como a las aves del cielo.

Sicut pisces maris.

Traduce: como a los peces del mar.

Sicut pecora campi.

Traduce: como a los animales del campo.

En los tres casos sobra el artículo, pues no se trata propiamente de un complemento del verbo («ni dan muerte a sus altanerías como a las aves del cielo») sino de una especie de aposición del sustantivo: a sus altanerías, cual aves del cielo. Así en los tres casos.

_-: Et sapientiae tuae non est numerus.

Traduce: Tu sabiduría no tiene límite. (En el contexto es necesario mantener la idea de «número» porque luego hablará «de ser contado», marcando el contraste entre quien «no tiene número» y es numerado).

V,5,8: Quis esset eius sensus in ceteris, quae abditiora sunt, manifeste cognosceretur.

Traduce: Se pusiera claramente de manifiesto cuál era su opinión en los demás asuntos más oscuros. (Lo que quiere decir: cuál era el valor de su opinión en otros asuntos más oscuros; no cuál era su opinión).

$\mathrm{V}, 8,14$ : Hinc insana facientes, inde vana pollicentes.

Traduce: haciendo unas veces locuras y otras prometiendo cosas vanas. (No se trata propiamente de momentos temporales, sino de dos fuentes de acción: por una parte... por otra; de un lado... de otro).

$\mathrm{V}, 12,22$ : Oderam etiam istos cor meum, quamvis non perfecto odio.

Traduce: Mi corazón los odiaba también, pero no con odio total. (No se trata de un odio total, sino de un odio legítimo, es decir, odiando en ellos el mal, pero amando a las personas, según pensamiento continuo del Santo). 
VI,4,6: Tantam illis auctoritatem tribuisti.

Traduce: dándole tanta eficacia. (La «auctoritas» es cosa distinta de la «eficacia»: es prestigio, es fuerza moral de atracción, etc.).

XIII,2,3: Ut simus iustitia tua... sicut montes Dei... sicut abyssus multa.

Traduce: ... como los montes de Dios... como el abismo tenebroso. (De nuevo sobra el artículo, porque se trata de una especie de aposición: como montes de Dios, ... como abismo tenebroso).

c) Es frecuente que no capte o, al menos, no mantenga las imágenes de que se sirve Agustín

II,1,1: Silvescere.

Traduce: embrutecerme (falta la imagen de la selva tupida y tenebrosa).

II,2,3: Et abscissus propter regunum coelorum.

Traduce: separado de todo por el reino de los cielos (falta la referencia al celibato).

III,5,9: Sed incessu humilem, sucessu excelsam et velatam mysteriis.

Traduce: humilde en el estilo, sublime en la doctrina y llena de misterios (falta la imagen de una casa con una entrada pequeña y humilde, pero grandiosa por dentro. Así en todo este capítulo).

IV,8,13: Cuius adulterina confricatione.

Traduce: con cuyo contacto engañoso (falta la imagen de la infidelidad matrimonial).

V,6,10: Quibus eos animo vagabundus audivi.

Traduce: sin poder fijar mi atención en ninguna.

Debe ser: durante los cuales, vagando con el alma (no con el cuerpo), los escuché (falta la imagen del vagabundo espiritual que no corporal).

V,6,10: Vultus congruus.

Traduce: porque su rostro fuera agraciado. (No ha entendido la referencia a las normas retóricas de acomodar el gesto al tema que se trata. No es el rostro agraciado, sino el gesto adecuado).

$\mathrm{V}, 12,22$ : Certe turpes sunt tales et fornicantur abs te.

Traduce: naturalmente son infames los que obran así y se apartan de ti. (No mantiene la imagen del hombre lascivo e infiel a su cónyuge).

VI,5,7: Pertractans et componens cor meum.

Traduce: Hiciste poco a poco el tratamiento y la cura de mi corazón. (No mantiene la imagen del alfarero que con la mano da forma al cacharro).

VII,16,22: Et tumescentis foras. 
Traduce: y se muestra orgullosa por el exterior. (No mantiene la imagen de un miembro hinchado).

VIII,6,15: Et relicta militia saeculari servire tibi.

Traduce: y dedicarse a tu servicio, abandonando las preocupaciones del mundo. (No mantiene la imagen militar).

-_: Et turbidus parturitione novae vitae.

Traduce: y turbado por la decisión que había tomado de una nueva vida. (No mantiene la imagen del sufrimiento de la mujer que da a luz).

VIII,6,15: Et aedificabant turrem sumptu idoneo...

Traduce: comenzaron a edificar la torre... con la condición indispensable. (No mantiene la idea de que toda construcción requiere unos gastos, un precio).

VIII,11,27: Dignitas continentiae.

Traduce: la dignidad de la virtud de la continencia. (No mantiene la prosopopeya).

VIII,12,30: Triumphat.

Traduce: se alegraba muchísimo. (No percibe la imagen militar de celebración de una victoria).

IX,5,13: Venditorem verborum.

Traduce: otro profesor de retórica. (Desaparece la imagen del profesor como mercader).

d) Supresión o adición de texto

1) Falta texto (lo señalado en cursiva)

IV,2,3: Theatrici carminis certamen.

IV,7,12: Quo non me sequerer?

IV,15,24: Tante rei cardinem in arte tua.

$\mathrm{V}, 1,1$ : Per os considerantium ea.

VI,4,5: Puerili errore.

VIII,3,8: Et quaedam de te cirta te...

$\mathrm{XI}, 2,3$ : Lux caecorum et virtus infirmorum statimque lux videntium et virtus fortium.

2) Introduce texto:

II,5,11: Investiga también, si quieres, por qué es así.

VIII,2,3: Me recordó después al obispo Victorino.

e) Contenido de las notas. No faltan imprecisiones ni, incluso, errores

a I,2,2 (nota 2): Doble sentido de invocare: llamar a voces e invocar. Esta ex- 
plicación no responde a la traducción hecha, ni plenamente a la realidad. Invocar: llamar a un lugar (vocare in) y «suplicar».

a I,4,4 (nota 4): Charlatanes mudos parecen ser los maniqueos porque no le hablaban de Dios. (Quizá sea más exacto pensar que Agustín les atribuye esa mudez porque no hablaban de Dios, sino de sus phantasmata [III,6,10]).

a I,5,5 (nota 5). Falta otra traducción posible, que creemos la más fiel al pensamiento de Agustín: muera yo (al pecado) para no morir (muerte total de cuerpo y alma) y así poder verla.

a I,6,7 (nota 7): No distingue el problema del origen del alma del de su preexistencia. Fue sobre el primero de ellos, más que sobre el segundo, sobre el que Agustín no llegó a encontrar una solución satisfactoria.

a III,11,19 (nota 11): Indica que no sabemos en qué casa vivió cuando le expulsó su madre. Pero no es cierto, pues, él mismo nos indica que le acogió Romaniano (Contra Academicos II,2,3).

a IV,1,1 (nota 1): Indica a los elegidos como el último grado de la jerarquía maniquea, cuando en realidad no había más que dos: el de los oyentes y el de los elegidos, siendo este último el grado a que pertenecía toda la jerarquía. Es decir, no es un grado más entre la jerarquía, sino el grado común al que pertenece toda la jerarquía.

a VII,19,25 (nota 12): Hace a Fotino obispo de Limnio, cuando en realidad lo fue de Sirmio. Error al que probablemente le condujo la misma nota de la edición del P. Custodio Vega.

\section{f) Errores tipográficos}

1,7,11: ¿En qué (=que) deseaba con ansia el pecho...?

-_: para mi (=mí) obedecer...

1,13,22 (nota 6): columnas = cortinas.

II,9,17: engañábámos.

III,3,6: como (=con) una especie de vergüenza por no ser uno de tanto $(=$ tantos $)$.

V,5,9: detestado $(=\mathrm{a})$ y arrojado $(=\mathrm{a})$ lejos.

$\mathrm{V}, 7,12$ : prolijas historia $(s)$.

V,7,13: separa $=$ repara.

VI,10,16: sino también con (falta) el aguijón del temor.

VI,16,26: sobre el (falta) grado máximo de los bienes y los males.

VIII,10,22: Mirad lo que decía (= decís).

IX,2,2 (nota 1): cavaciones = vacaciones.

IX,4,7: efectivamente $=$ afectivamente.

IX,4,10: contra sí mismos para (falta) el día de la ira.

IX, 7,15: $s u(=t u)$ sierva. 
IX,8,18: llamándole (=la) borrachuela.

IX,12,31: acompañado de los que no (falta) creían conveniente dejarme solo.

$\mathrm{X}, 6,9$ : puede $=$ pude.

$\mathrm{X}, 8,14$ : en el depósito inmenso de (falta) mi alma.

$\mathrm{X}, 9,16$ : cuya realización ( $=$ realidad).

$\mathrm{X}, 23,34$ : pero se encontrará con que no (falta) podrá ocultarse ante la verdad.

$\mathrm{XI}, 2,2$ : y la oscuridad que aún que $(=\mathrm{me})$ queda ahora.

$\mathrm{XI,7,9:} \mathrm{Por} \mathrm{eso} \mathrm{es} \mathrm{(falta)} \mathrm{con} \mathrm{tu} \mathrm{palabra} \mathrm{eterna.}$

$\mathrm{XI}, 8,10$ : En la vida (=verdad) eterna.

XIII,6,7: Falta el 7.

XIII,19,25: Hay (= Haya) lumbreras en el firmamento.

XIII,21,29: Aunque como (=coma) el pez.

XIII,28,43: A partir de aquí ya no se corresponden los capítulos y parágrafos.

\section{g) Lenguaje castellano}

A nivel de lengua castellana, a nuestro parecer, deberia haber hecho más uso de los pronombres, para evitar repeticiones frecuentes y cercanas del mismo sustantivo (por ej.: I,10,16: espectáculos... espectáculos; I,13,22: caminos... caminos; VI,9,15: foro... foro; IX,13,34: deudas... deudas). Si en ese sentido podemos hablar de escasez en el uso del pronombre, se puede hablar igualmente de abuso del artículo que en circunstancias cambia el sentido del texto (por ej.: II,4,9: la abundancia de la maldad; III,6,11: por falta de la verdad; VI,5,7: que dice $l a$ verdad, etc.). Encontramos también expresiones poco correctas (por ej.: VI,2,2: ceder... de seguir practicando; I,14,23: cuando se les obligue a aprenderlo, como yo a Homero = como a mí a Homero); correspondencias inadecuadas entre los verbos (por ej.: XII,26,36: ¿qué es el hombre, si no te acordaras de él?...; XII,26,36: los que ya las entendieran, encontrarán que en cualquier afirmación...; VII,2,3: ... qué podía hacerte... si no querías luchar con ella).

En conjunto se obtiene la impresión de que el traductor no está familiarizado con el pensamiento y el lenguaje del autor al que traduce y por eso no siempre acierta a trasmitir con fidelidad el pensamiento del Santo. Las observaciones que le hemos hecho, muchas ciertamente, aunque no todas las que recogimos en nuestra lectura, no son todas de la misma entidad. Si bien es cierto que en muchos casos se trata de opciones nuestras, a las que se pueden oponer otras opciones desde el respeto a la gramática, en otros muchos se trata de errores objetivos, fruto quizá muchas veces del descuido. El libro gana respecto a muchas otras ediciones anteriores en facilidad de lectura, pero no en trasmitir fielmente el pensamiento de Agustín, a pesar de que ésa haya sido la intención explícita del traductor. 


\section{D) La traducción de José Cosgaya, OSA}

Su publicación, en la BAC minor, es recentísima. El formato, como es lógico, es el habitual de la colección $(17,5 \times 10)$. Su presentación, exterior e interior, es impecable. Encuadernada como está resulta de muy fácil manejo.

La obra la introduce una PRESENTACIÓN de Pedro Rubio, OSA. En poco más de tres páginas presenta a la vez a Agustín como hombre con un mensaje, un estilo, para nuestro tiempo; a las Confesiones, «no sólo historia de Agustín en la búsqueda de Dios, sino, y sobre todo, como historia de Dios en la vida de Agustín»; y a la presente traducción, cuyo intento señala: «facilitar la comprensión a los lectores de habla hispana, siendo fiel al propio san Agustín, sin recortar ni diluir su pensamiento; y siendo fiel a las exigencias cambiantes de los tiempos, sin ceder por ello al convencionalismo u optar por la ruptura».

La edición ofrece la obra agustiniana en la totalidad de sus trece libros, divididos éstos en los capítulos y números tradicionales. Cada capítulo lleva su propio epígrafe, no así los libros. Incluye dos series de notas. La primera en números arábigos que recogen las referencias a otras fuentes del escrito agustiniano. Obviamente las citas escriturísticas ocupan un porcentaje elevadísimo de las mismas, pues incluye no sólo las citas explícitas, sino también las simples alusiones, fenómeno que se da tan frecuentemente en la obra. Es precisamente mirando a este índice como se percibe uno de los rasgos característicos de la obra agustiniana: su lenguaje e imágenes bíblicas. En cuanto a otras referencias, las profanas, recoge sólo las explícitas que, en el conjunto, significan una mínima parte. Una segunda serie, en letras, contiene notas explicativas del texto. De extensión desigual, están tomadas en su mayor parte de la edición del P. A. Custodio Vega, la hermana mayor, en cuanto aparecida en la BAC normal (vol. II de las Obras de San Agustín. Véase antes I C). Ha excluido las eruditas y se ha limitado a las que ayudan directamente a la comprensión del texto. No son excesivamente numerosas y en algún caso el lector echará de menos la oportuna explicación (por ej. en III,6,11 a propósito de los cinco elementos y los cinco antros del reino de las tinieblas).

Todo el texto va en el mismo tipo de letra, redonda. Ni las citas bíblicas ni cualesquiera otras citas explícitas aparecen en cursiva. El hecho que puede parecer sin importancia contribuirá en esta obra a una lectura más completa y a saborear mejor el texto agustiniano.

Consideremos ahora la traducción en sí misma. A nuestro juicio es la mejor de todas las recensionadas hasta el momento, considerada en su globalidad, es decir, combinando la fidelidad al pensamiento agustiniano, la fluidez en el castellano y la inteligibilidad del texto.

La traducción sigue muy de cerca al texto original, en cuanto a su conte- 
nido. No es esclava de la letra, pero tampoco se toma libertades innecesarias. Salvo algunos errores o imprecisiones puntuales, a que luego haremos referencia y que es raro que estén totalmentre ausentes de este tipo de obras, es mucho más de fiar que las últimas recensionadas. Más allá del puro calco fonético, vicio tan frecuente en las traducciones del latín a las lenguas románicas, atiende a la correspondencia semántica de los términos. A veces, sin embargo, debido al estilo castellano, pierde matices indicados por las partículas latinas, que no siempre son vertidas. El estilo de la frase corta, con puntos frecuentes, elimina en ocasiones matices de causalidad, consecuencia o concesión, que siempre son de valor y permitirían comprender mejor el pensamiento del autor.

El P. Cosgaya es una persona ya avezada en el arte de la traducción y buen conocedor del idioma castellano, realidad que se percibe desde la primera página. La lectura de la obra se hace fácil, resulta cómoda y agradable. La frase, como ya indicamos, es corta y lineal, sin recovecos. Ha sabido desprenderse de la latina subyacente para plasmar el pensamiento de Agustín en frase puramente castellana. Del latín original no se percibe ni el eco lejano. El léxico no es rebuscado, pero tampoco vulgar, y siempre ajustado al lenguaje actual. Al mismo tiempo, suele mantener fielmente las imágenes literarias del Santo.

Una y otra realidad, la fidelidad al pensamiento original y el dominio del idioma castellano da como resultado la inteligibilidad del texto. Las Confesiones no son una obra que resulte fácil de entender, sobre todo en algunas de sus partes o libros. No vamos a decir que la presente traducción resuelve todos los problemas de intelección, que siempre serán muchos para todo lector y más para el no especialista o no habituado al trato con libros de este estilo y época, pero sí que la facilita. Aun el difícil libro XIII, por ejemplo, se sigue con relativa facilidad.

Tampoco es una obra perfecta. La simple lectura ha permitido detectar fallos sea de traducción errónea, sea de lagunas en el texto, sea incluso errores de imprenta, pero de mucha menor entidad y número que en las ediciones que hemos visto anteriormente. En un juicio comparativo, esta edición saca notable ventaja a las anteriores.

\section{a) Defectos de traducción o interpretación}

II,2,2: Sed non tenebatur modus ab animo usque ad animum, quatenus est luminosus limes amicitiae.

Traduce: Pero me faltaba el justo equilibrio en el amor que va de alma a alma, dado que las fronteras de la amistad son algo luminoso. Debe ser: Pero me faltaba la justa medida: el amor que va de alma a alma, límite dentro del cual la amistad es luminosa. 
II,6,14: Et quaerit extra te ea quae pura et liquida non invenit, nisi cum redit ad te.

Traduce: aquellas realidades que no se dan auténticamente puras, mas que cuando el alma vuelve a ti.

Debe ser: que el alma no halla en su pureza, más que cuando vuelve a ti (no es que no se den, que no existan, sino que el alma no las alcanza).

III,3,6: Et inter quos vivebam pudore impudenti, quia talis non eram.

Traduce: entre ellos mantenía una actitud medio cínica, medio decente, porque en el fondo no era ni me consideraba como uno de ellos.

Debe ser: sentía una vergüenza falta de pudor al no ser como ellos (implica el sentimiento de vergüenza porque él no era como los demás).

III,7,12: Et quid in nobis esset, secundum quod essemus, et recte in Scriptura diceremur ad imaginem Dei, prorsus ignorabam.

Traduce un tanto enrevesado: Desconocía qué es lo que hay en nosotros que motive aquello por lo que somos hechos a imagen de Dios... Debe ser traducido de forma más sencilla: Desconocía lo que hay en nosotros por lo que somos y en verdad se nos indica en la Escritura como hechos «a imagen de Dios».

III,11,19: Qui cum causas... quaesisset... docendi ut adsolet, non discendi gratia...

Traduce: No con ánimo de enterarse, como ocurre de ordinario, sino, con intención de aconsejarla.

Debe ser: No con ánimo de enterarse él, sino como ocurre de ordinario, con intención de aconsejarla.

IV,3,4: Quam totam illi salubritatem interficere conantur.

Traduce: ... dar al traste con nuestra salvación.

Debe ser: cuya eficacia salvadora (de las palabras antes citadas) intentan destruir.

V,5,9: ... nondum... compereram, utrum... posset exponi, ut, si forte posset, incertum quidem mihi fieret, utrum ita se res haberet.

Traduce: caso de que la explicación fuera posible yo me sentiría perplejo y no sabría a qué atenerme.

Debe ser: en el caso de que hubiera existido esa explicación, yo me hubiera sentido perplejo, y no hubiera sabido a qué atenerme (indicando irrealidad).

V,7,12: Quorum quidem ignarus posset veritatem tenere pietatis, sed si manichaeus non esset. 
Traduce: Cierto que, aunque eran muchos sus conocimientos en tales materias, esto no quiere decir que careciera de la posesión de la verdad religiosa...

Debe ser: Cierto que, aunque hubieran sido nulos sus conocimientos en tales materias, habría podido poseer la verdad religiosa...

V,10,20: Hinc enim et mali substantiam quamdam credebam esse talem et habere suam molem...

Traduce: De esta actitud errónea arranca mi creencia de que la sustancia del mal era, asimismo, corpórea.

Debe ser: ... arrancaba ... (para no dar a entender que tal creencia la mantiene cuando escribe).

VIII,9,21: Quia non totus assurgit veritate sublevatus, consuetudine praegravatus.

Traduce: No se levanta todo él empujado por la verdad, sino avasallado por la costumbre.

Debe ser: ..., al estar avasallado por la costumbre.

$\mathrm{X}, 40,65$ : ... et nihil eorum te esse inveni. Nec ego ipse inventor, qui peragravi...

Traduce: ... Y descubrí que ninguna de esas cosas eras tú. Y no fui yo mismo el descubridor...

Debe ser: ... tampoco lo era (=Dios) yo, el descubridor, yo que...

\section{b) Lagunas en el texto}

II,8,16: Falta: et nihil aliud.

IV,3,4: Falta: aut Mars.

VIII,3,7: Falta por expresar un non.

Traduce: por quienes sorbían los vientos siendo novios.

Debe ser: por quienes no habían suspirado siendo todavía novios.

\section{c) Errores tipográficos}

III,3,6: Sus ultrajes obedecían $a$ (falta) otros móviles que los de servir.

V,2,2: Leemos: Colisionaron contigo, injustos para su justa afrenta (falta la «coma» después de injustos).

VIII,5,10: Leemos: tu palabra. Debe ser: tu Palabra.

$\mathrm{X}, 2,2$ : Leemos: pueden. Debe ser: puedes.

XIII,9, 10: Leemos: de su Espíritu. Debe ser: de tu Espíritu.

En nota 206, p. 268: Leemos: Cfr. 50,15. Debe ser: Cfr. Sal 50,15.

En nota 25 , p. 64 , se indica el nombre del autor, pero no el título de la obra a que se hace referencia. Lo mismo en pp. 114, 115 y 272. 


\section{E) La traducción del P. Lope Cilleruelo, OSA}

Todavía no disponemos de ella. Aparecerá, como ya indicamos, en Ediciones Cristiandad. Desconocemos la colección y el formato.

Nos consta que llevará una introducción del Prof. Rof Carballo, pero carecemos de más datos al respecto.

De la traducción podemos afirmar, por haberla leído antes de ser enviada a la imprenta hace ya más de dos años, que se mantiene en la misma línea de la anterior: seguimiento cercano del texto latino en cuanto a su contenido, atento a los matices incluso, pero libertad literaria frente a él. El P. Lope Cilleruelo a quien la muerte vetó tener en sus manos esta obra que él había soñado realizar desde hacía mucho tiempo y que emprendió cuando ya sabía que tenía los días contados, era uno de los españoles que mejor conocían a san Agustín. Eso es una garantía para el lector de que tendrá en sus manos el auténtico pensamiento del Santo. Por otra parte, era un hombre de una inteligencia privilegiada para captar la idea y de una pluma ágil para saber expresarla con nitidez. Así muchos textos, sin duda intrincados, se resuelven en claridad. Enamorado de lo clásico, se deja llevar a veces del gusto por ciertos arcaísmos, quizá en un intento vano de recuperarlos para el idioma. Consciente de ser un tanto descuidado y poco fino para ciertos detalles, supo suplir esa deficiencia buscando quien repasase el original de su traducción.

La obra aparecerá completa. La división será la tradicional en libros, capítulos y números. Los capítulos llevarán un epígrafe que, a nuestro juicio, será uno de los aspectos que harán más valiosa esta traducción, pues serán de gran ayuda para el lector, en cuanto que sobrepasan la praxis habitual de recoger el contenido material del mismo. Más que ese aspecto, busca ofrecer al lector lo que el Santo pretende decir con ese material. De esa manera, el epígrafe de cada capítulo es, con mucha frecuencia, la primera clave de interpretación de que dispone el lector.

Las notas se acomodan al destinatario primero del libro, que es el gran público, no el erudito y científico. Son breves y no demasiadas.

No dudamos de que será una edición hermosa, bien cuidada, habida cuenta del esmero que pone en sus publicaciones la Editorial Cristiandad, y que servirá para que muchos saboreen la obra de arte agustiniana.

Las obras maestras del arte sólo irradian toda su belleza y perfección a quien las contempla en su originalidad, no en sus copias o reproducciones. Éstas, por perfectas que sean, nunca logran trasmitir todo el encanto estético que proyecta el original. No obstante, tienen su función y son útiles a la causa 
del arte. Con frecuencia son ellas las que mantienen encendido ese fucgo sagrado. A quien no tiene la posibilidad de la contemplación directa, ellas le permiten un primer acercamiento y avivan el deseo de aquélla. No trasmiten todos los valores, pero, según la calidad de las mismas, sí una parte de ellos.

Pues bien, toda traducción de una obra de arte literaria es una copia del original. Por lo tanto, el tomarla en las propias manos ha de ser sólo el último recurso, cuando no exista la posibilidad del encuentro directo con el original. Pero no porque el acceso a la obra sólo sea posible a través de la copia se ha de desechar; aunque rebajada en quilates siempre nos permite un contacto con la obra maestra. Lo que se impone es, pues, prestar atención a qué reproducciones pedimos el servicio de ponernos en contacto con la obra de arte. Aplicado a nuestro caso concreto, se impone elegir con acierto la traducción que se piensa utilizar. En gran parte depende de este hecho el que la lectura se convierta en realidad y no se quede en simple deseo, convertido en irrealizable por no haber encontrado el instrumento adecuado. A facilitar esta elección hemos querido contribuir con estas páginas.

Pío DE Luis VIzCAíno 